\title{
Comparing the Educational Preferences and Management Roles of West Virginia's Male and Female Woodland Owners
}

\author{
Tiffany Fegel
}

Follow this and additional works at: https://researchrepository.wvu.edu/etd

\section{Recommended Citation}

Fegel, Tiffany, "Comparing the Educational Preferences and Management Roles of West Virginia's Male and Female Woodland Owners" (2014). Graduate Theses, Dissertations, and Problem Reports. 5584. https://researchrepository.wvu.edu/etd/5584

This Thesis is protected by copyright and/or related rights. It has been brought to you by the The Research Repository @ WVU with permission from the rights-holder(s). You are free to use this Thesis in any way that is permitted by the copyright and related rights legislation that applies to your use. For other uses you must obtain permission from the rights-holder(s) directly, unless additional rights are indicated by a Creative Commons license in the record and/ or on the work itself. This Thesis has been accepted for inclusion in WVU Graduate Theses, Dissertations, and Problem Reports collection by an authorized administrator of The Research Repository @ WVU. For more information, please contact researchrepository@mail.wvu.edu. 


\title{
Comparing the Educational Preferences and Management Roles of West Virginia's Male and Female Woodland Owners
}

\author{
by \\ Tiffany Fegel \\ A thesis submitted to the Faculty of Graduate Studies, \\ Davis College of Agriculture, Natural Resources, and Design \\ West Virginia University, WV \\ in partial fulfillment of the requirements for the degree of
}

Master of Science in Forestry

David McGill, Ph.D.; Chair

David Smaldone, Ph.D.

Kathryn Gazal, Ph.D.

Division of Forestry and Natural Resources

Morgantown, West Virginia, WV

September 2014

Key words: Private forest owners, female woodland owners, educational preferences 


\begin{abstract}
Comparing the Educational Preferences and Management Roles of West Virginia's Male and Female Woodland Owners

\section{Tiffany Fegel}

Non-industrial private forest owners (NIPF) make up the majority of the landscape in the eastern United States. Historically NIPF owners have been treated as a homogenous group. This however does not adequately represent the diversity of this population's ownership objectives, management concerns, and land values that are important in understanding how to tailor educational outreach programs to this group. Butler (2008) called for the need to separate this large population into smaller populations that are more homogenous in order to better reach them with educational programs. To answer this call we divided NIPF owners into two distinct groups, male and female woodland owners. In this research, educational preferences and management roles of woodland owners in West Virginia were investigated for differences among these two groups of owners.

Utilizing a mail-based questionnaire, four counties in West Virginia were surveyed with the objective of gaining a better understanding of the female population of woodland owners and managers. Principal component analysis and logistic regression were used to analyze the data collected. Results show that management roles greatly differ between genders, however, educational preferences are not as clearly defined.
\end{abstract}




\section{ACKNOWLEDGEMENTS}

I would like to thank my advisor Dr. Dave McGill for all of his guidance and encouragement from the beginning of this journey to the beginning of another. Thank you.

Also, my committee members Dr. Dave Smaldone and Dr. Kathryn Gazal for their time, support, and expertise. Thank you.

I would like to thank the many wonderful woodland owners of West Virginia that I was fortunate enough to work with. I will be forever grateful to the Frack's and the White's for opening their homes and hearts to me and being my West Virginia family. Thank you.

To all of my friends back home who have stuck with me in this crazy adventure, thank you for your love and encouragement. And to the friends I have made in West Virginia. Val, you are amazing! I love you all. Thank you.

I would like to thank my mom and dad for everything they have given me to get me here... from grocery money to more love than anyone could ask for. Dad you will always be my voice of reason and my number one for proof reading. Mom words cannot describe how thankful I am for your constant encouragement. Seeing a package on my doorstep made my day more times than I can count. It's the little things. I love you both. Thank you.

To my little brother and sister, Tay \& Trap, for reminding me who I am and why I can never give up. You guys are an inspiration to me. I love you both. Thank you.

To my Grams and T for always being my biggest cheerleaders. Gramsy you have taught me so much about life and finding my happiness no matter where this life takes me. $\mathrm{T}$ this one is for you, thank you for being my biggest fan, my personal bank, and for believing in me since day one. I love you both. Thank you.

Finally, I would like to thank the Lord for providing me with so many great opportunities and for the people in my life that I have been blessed to share them with.

My goal has always been to make you all proud. 


\section{TABLE OF CONTENTS}

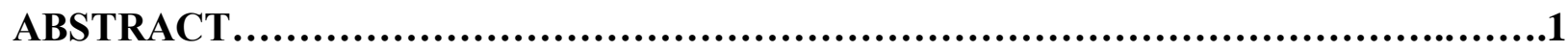

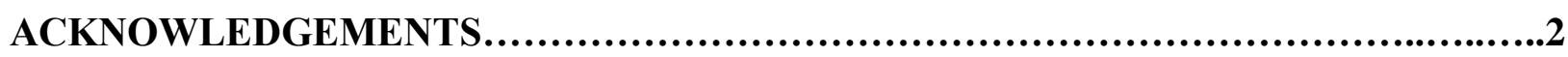

LIST OF FIGURES......................................................................

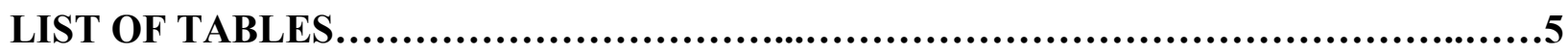

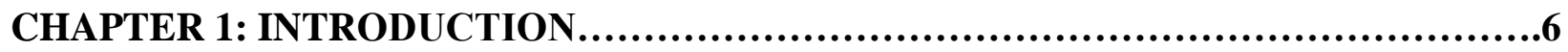

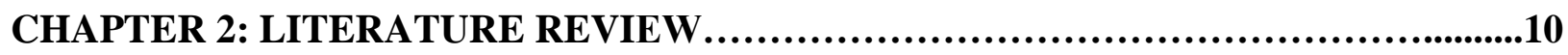

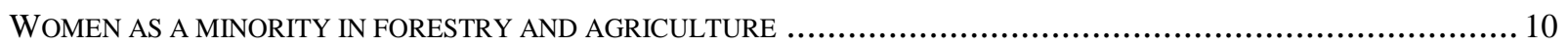

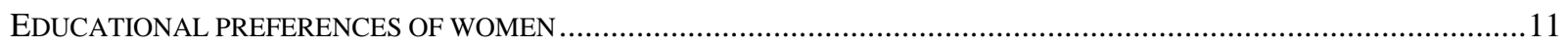

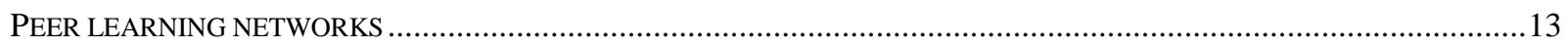

CHAPTER 3: METHODOLOGY .........................................................16

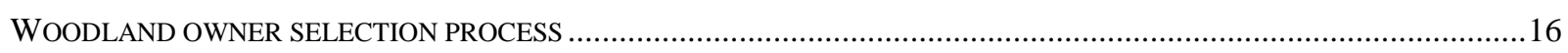

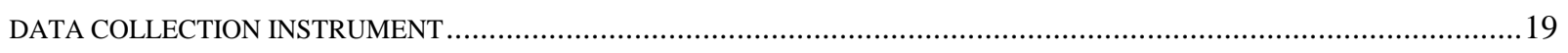

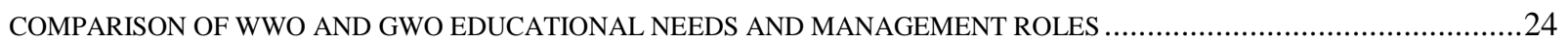

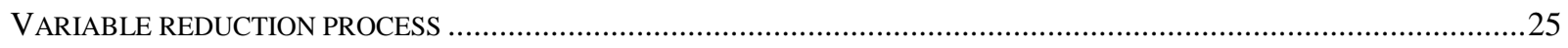

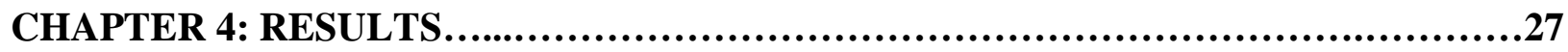

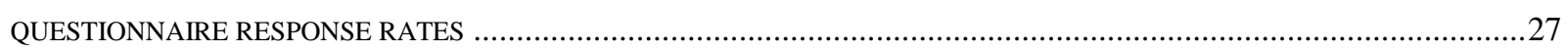

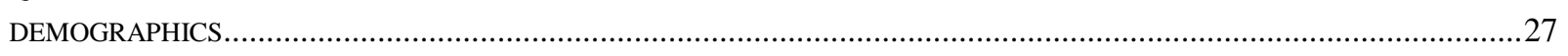

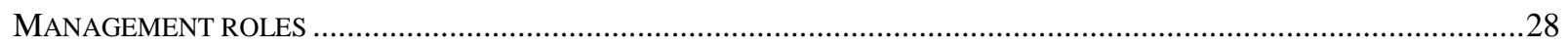

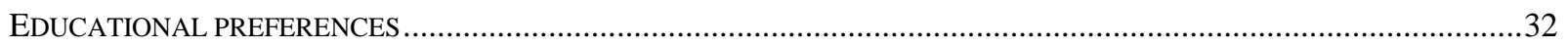

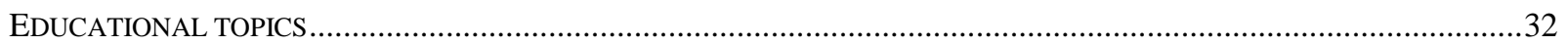

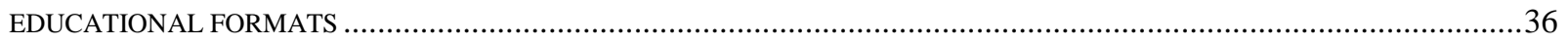

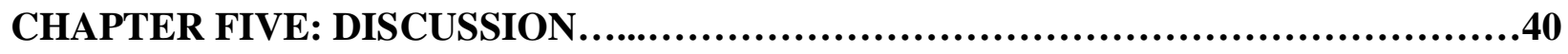

LITERATURE CITED..................................................................44

APPENDIX A. PRE- SURVEY POSTCARD...........................................47

APPENDIX B. INITIAL COVER LETTER.......................................48

APPENDIX C. SURVEY/KEY ....................................................50

APPENDIX D. REMINDER POSTCARD..........................................56

APPENDIX E. REMINDER LETTER.................................................57 


\section{LIST OF FIGURES}

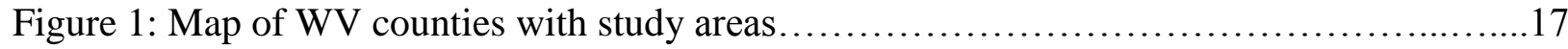

Figure 2: GWO survey cover photo and introductory paragraph..........................20

Figure 3: WWO survey cover photo and introductory paragraph........................20

Figure 4: Question 15 related to management activities................................22

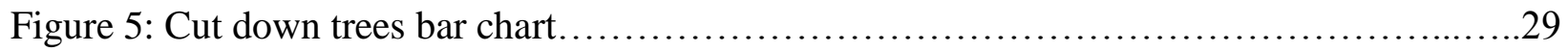

Figure 6: Talk with neighbors about woodland issues bar chart.......................... 30

Figure 7: Recreational walking bar chart........................................... 30

Figure 8: Eigenvalue components topics........................................ 33

Figure 9: Eigenvalue components formats......................................... 37 


\section{LIST OF TABLES}

Table 1: Demographics related to age, education, and income...........................28

Table 2. Logistic regression of management activities.....................................

Table 3. Survey items for workshop topics.......................................... 35

Table 4. Logistic regression analysis of educational topics................................ 36

Table 5. Survey items for educational formats..........................................

Table 6. Logistic regression analysis of educational formats................................ 


\section{Chapter 1: Introduction}

This chapter will briefly provide an overview of this research project. Background information is presented first, followed by a problem statement, the purpose of the research, research questions, and finally an overview of the remainder of this thesis.

\section{Background}

Non-industrial private forest owners (NIPF) make up the majority of the landscape in the eastern United States (Crim, Dubois, Bailey, \& Schelhas, 2003). Historically NIPF owners have been treated as a homogenous group (Butler, 2008). This however does not adequately represent the diversity of this population's ownership objectives, management concerns, and land values that are important in understanding how to tailor educational outreach programs to this group. Butler (2008) calls for the need to separate this large population into smaller populations that are more homogenous in order to better reach them with educational programs.

This research project is based on extension outreach education. Extension is outreach education derived from research at the university level focused on extending that knowledge beyond the academic world. Looking at the issue of gender in forestry through the lens of extension is logical because extension outreach has the freedom to develop programs based on the needs and desires of the people it serves (Sanders, 1966). If this research reveals that there is a need for forestry outreach programs focused on engaging women, this information could be utilized by extension to implement such a program in West Virginia. Extension also aims to educate adults in the elementary science of agriculture and up-to-date farm practices by encouraging individuals to change their physical behavior and mental perspective for immediate application in solving whatever problems they are facing (Sanders, 1966). This will directly tie 
into the concept of empowerment (Page \& Czuba, 1999) that will be discussed further in chapter two.

Women compromise a substantial sub-population of forest land owners (Warren, 2003) and could be an important sub-population of the non-industrial private forest owner population to target as Butler (2008) calls for. Of the approximate 243,000 family forest owners in West Virginia (Widmann et al., 2012) 19,000 of them are women who are sole owners (Butler, Miles, \& Hansen, 2013). When the reported 21,000 jointly owned forest parcels (Butler, et al., 2013) in the state are considered, 40,000 of these properties include women decision makers (Butler, et al., 2013). The proportion of women reporting sole ownership in West Virginia is slightly lower that the nationwide average of 26\% (Butler, 2008). According to the newest United States Forest Service National Woodland Owner Survey, the percentage of women woodland owners has increased by 5 percent from 19 percent in 2006 to 24 percent in 2011 (Wilent, 2013). This change is most likely the result of one of three reasons: 1) women have inherited lands from parents, 2) they have outlived their spouses, and 3) more women are buying forested property for their own purposes (Effland, Rogers, \& Grim, 1993; Warren, 2003).

\section{Problem Statement}

Many women face discrimination and other barriers in their forestry roles (Barbercheck et al., 2009) which causes them to seek alternative outlets of exchanging knowledge, out of the spotlight of their male counterparts, so as not to be criticized (Trauger et al., 2008). The theory of homophily will later be used to provide potential reasoning for this.

According to a study of the offspring of forest owners nationwide, 83 percent of women sampled said they would like to take over the family forest in the future. However, only 34 percent felt as though they had the amount of knowledge needed to make management decisions 
(Mater et al. 2005). Thirty-six percent of female landowners describe a lack of knowledge as a barrier to owning woodlands (Mater et al., 2005).

The theory of empowerment (Page \& Czuba, 1999) will be utilized to describe how knowledge and education are essential for women to overcome the perception that forestry is a field for only men. Both theories of empowerment and homophily (Rogers, 2010) will be utilized in describing the potential of peer learning networks to break down barriers for women in forestry.

\section{Research Questions}

In order to seek new ways to engage with and support women in pursuing woodland stewardship, this study will investigate the educational preferences and the woodland management roles of women woodland owners in West Virginia focusing on two primary research questions:

Q1. Do management roles differ between male and females in woodland management in West Virginia?

Q2: What are the educational preferences of women woodland owners and do these differ from those of their male counterparts?

\section{Thesis overview}

Chapter two of this thesis provides a review of the literature in regards to women as minorities in forestry, educational preferences of women, peer-learning networks as a method of outreach education, and the theories of empowerment and homophily. Chapter three presents the research techniques, including the process of woodland owner selection and survey methods. 
Chapter four provides the findings of this research. Finally, chapter five discusses the conclusions, including a review of the key findings and future research suggestions. 


\section{Chapter 2: Literature review}

\section{Women as a minority in forestry and agriculture}

Forestry is a historically male-dominated profession and the cultural perception of it being most suitable for men is the primary reason more women do not engage in the forestry sector (Redmore, 2009; Redmore \& Tynon, 2011; Trauger, et al., 2008). The majority of forest policy decisions still utilize a framework that was created by men for men (Leckie, 1996; WOCAN, 2012) forcing women to continuously fight historical gender roles (Reed, 2004). Much of the literature in this field has been done on women in agriculture. Although direct links can be made, more research is needed on women in forestry management roles.

The roles of farmers and foresters have been socially constricted by gender for centuries (Leckie, 1996; Lidestav and Ekstrom, 2000; Trauger, et al., 2008) which "contributes to the marginalization of women from knowledge exchange and decision-making roles" (Trauger, et al., 2008)

The perception that particular responsibilities are appropriate for one sex over another is a key principle in role theory (Eagly, Wood, \& Diekman, 2000). This theory argues that perceptions of the appropriate roles for each sex are culturally constructed (Barbercheck, et al., 2009; Eagly, et al., 2000; Redmore, 2009; Reed, 2004). Individuals generate these ideas based on observations of the roles of men and women and therefore reflect the sexual division of labor and gender hierarchy of society (Biddle, 1986). Role theory aims to explain underlying causes of gender differences by explaining that these differences are caused by socially constructed ideals.

Women do not feel as though they automatically have the right to be in these roles because it has been socially constructed that men are the appropriate candidates to fill them 
(Leckie, 1996; Lidestav and Ekstrom, 2000; Trauger, et al., 2008). Women who are in forest management positions express the need to constantly prove themselves in male-dominated situations (Lidestav and Ekstrom, 2000; Redmore \& Tynon, 2011). If this feeling of having to prove oneself is experienced at educational events, women are not able to focus on learning, nor feel welcome to engage and contribute (Trauger, et al., 2008).

When asked about the barriers to successful farm operations, 64 percent of women farm owners described not being taken as seriously as men as a key issue (Barbercheck, et al., 2009). Women not feeling welcome in many agricultural groups was also an issue for over half of the women (Barbercheck, et al., 2009).

\section{Educational Preferences of Women}

The previously discussed social stereotypes that make women a minority in forestry affect women's forest management objectives and education preferences (Crim, et al., 2003) and are evidence to the point that women need different information, presented in different formats, in order to help them manage their properties.

In a study done by Trauger et al. (2008), most of the female participants reported that they had significant gaps in their agricultural education. Qualitative interviews done by Redmore and Tynon (2009) revealed that some women felt they did not have the knowledge to know if the management activities they were carrying out on their property were correct. Both studies highlight the need for direct, more efficient, outreach education to women land managers.

In addition, most adult female farmers have at least one area of farming that they are not well educated in (Leckie, 1996). Often the questions they have in these areas are considered basic knowledge. These 'simple' questions that are essential in the learning process are often regarded as trivial by the males who have more expertise in these areas (Leckie, 1996). Women 
farmers in educational settings have indicated that asking for information often made them "feel vulnerable to social judgment" and would "expose their inexperience to other farmers" causing them to be "vulnerable to ridicule" (Leckie, 1996, p. 310). This is likely due to the perception that their questions are not significant compared to their male counterparts (Redmore \& Tynon, 2011). In order to prevent these feelings, women in farming roles tend to avoid educational opportunities that force them to interact with their male counterparts and become very selfsufficient (Leckie, 1996), often relying on written materials in order to prevent interaction with male counterparts or to prepare themselves for such interactions (Leckie, 1996).

In a study done by Trager et al. (2008) women in the agriculture field indicated that they prefer learning about stereotypically male skills from other women farmers who understand their limitations and restrictions. In a qualitative study of female landowners many participants indicated they typically acquire information from sources in which they have built trust such as family and friends (Crim, et al., 2003). Women landowners place the most value on information that comes from individuals they know have their best interests in mind rather than professionals (Crim, et al., 2003; Trauger, et al., 2008).

The idea that women prefer to compile knowledge from people with whom they trust directly relates to the theory of homophily. Homophily is the "degree to which two individuals who communicate are similar" (Rogers, 2010). The theory states the more homophilous individuals are with one another, the more likely communication will occur and the more effective that communication will be (Rogers, 2010). 


\section{Peer learning networks}

In peer learning networks often the goal is to create homophilic environments by bringing together people with similar characteristics and objectives in order for them to more easily communicate amongst each other (Allred, Goff, Wetzel, \& Luo, 2011; Barbercheck, et al., 2009; Redmore, 2009). Network-style communication makes women feel welcome and more inclined to attend outreach programs (Trauger, et al., 2008). Often these networks are formed with other women who have proven to each other that they are supportive and nonjudgmental (Leckie, 1996).

Being involved in natural resource based communities such as peer learning networks can be an important component in overall awareness of forest management and can "serve as an access point to the information that women in forest management need to know" (Redmore \& Tynon, 2011, p. 56). They aid with the information gathering and knowledge development process that can be difficult for women who are new or unfamiliar with agriculture and forestry roles.

Network style learning allows for the ease of creating horizontal knowledge flows amongst participants (Trauger, et al., 2008). Horizontal knowledge flows, in this context, are described as local knowledge that one woman who is part of a network is able to share with another women who is her peer (Mom, Bosch, \& Volberda, 2005; Trauger, et al., 2008). Peer learning networks stray from the traditional top-down teaching methods that often prevent horizontal knowledge exchange at educational events. This concept lends well to the desire that many women have to participate in interaction and education amongst one another (Trauger, et al., 2008). Peer learning networks also help women overcome some of the barriers to entering forestry (Redmore \& Tynon, 2011). 
Peer learning networks are comprised of voluntary members who see themselves as similar to each other and are not professional educators but participate in nonhierarchical learning with one another (Allred \& Sagor, 2011). A few examples of peer learning networks for women can be found in the United States. One is Oregon's Women Owning Woodlands network (WOWNet) that was developed in 2005 to recognize the growing number of women in woodland management roles, provide hands on educational opportunities for women, support women's access to forestry related resources, and encourage communication among Oregon women woodland owners (Redmore \& Tynon, 2011). Another network in the eastern U.S., Women in their Woods, was formed based on realizations that throughout the Pennsylvania region increasingly more women were becoming responsible for private forest lands (PSUExtension, n.d.). The primary focus of Pennsylvania's peer learning network is to promote confidence among its members through a "fun, dynamic, and informative program that teaches women how to responsibly manage their timber lands," (PSUExtension, n.d.). Topics covered in their monthly meetings include setting goals and objectives for forestlands, identification and eradication of invasive plant species, and cost-sharing opportunities.

Peer learning groups allow for the trusting and non-threatening environment that women prefer. They are also beneficial for women to be able to communicate with one another regarding subjects and challenges that are less familiar to their male counterparts.

Often peer-learning networks utilize the theory of empowerment (Allred \& Sagor, 2011; Redmore, 2009). This theory views individuals not as passive receivers of information but as people who are able to take information and use it in a way that is most suitable for their needs (Redmore, 2009). Empowerment is viewed as a process that challenges the assumptions we have about the way things are currently and how they can be in the future (Page \& Czuba, 1999). It is 
a social process and in this context the concept of 'relational power' means that gaining power strengthens the power of others as well as oneself and gives the participant the capacity to implement that power for use in their own lives (Page \& Czuba, 1999). In a focus group conducted by Trauger et al. (2008) communication and education among women about stereotypical male skills and basic management concepts extended "agency and empowerment to women." (Trauger et al., 2008, p. 436) This study also points out that education in itself is empowering and that through education women are able to gain agency by the acquisition of knowledge (Trauger, et al., 2008).

Previous research indicates a gap in knowledge for women in agriculture. This research project attempts to gauge where those gaps exist for female woodland owners by quantifying what women are most interested in learning and how they would prefer to obtain knowledge. 


\section{Chapter 3: Methodology}

A mail-based questionnaire was used to explore differences in the educational needs and management roles among male and female woodland owners in West Virginia. This survey instrument provided a means to obtain a time efficient and representative sample of the diversity of woodland ownerships from four counties across the state.

\section{Woodland owner selection process}

Property tax data from Fiscal Year 2013 was gathered to select woodland owners for the sample. Wood, Randolph, Hampshire, and Greenbrier counties (figure 1) were selected as the counties of interest in this survey as they provide a wide geographic representation of West Virginia woodland ownership. Geographically these counties represent the northern (Hampshire) and southern (Greenbrier) regions of the Valley and Ridge Physiographic province, the high mountains of the Allegheny Mountains section (Randolph), and the dissected Appalachian Plateau (Wood). These counties were also selected to avoid survey fatigue as they have not been included in recent woodland owner surveys recently conducted in West Virginia counties. Parcel information was obtained with permission from the county tax assessors of the counties of interest. Assessors were required to fill out a release form and submit it to the West Virginia Tax Department (WVDT). The WVDT then produced an electronic file containing property owner addresses and acreage. Specifically, the tax data includes the names and addresses of the parcel owners, the property sizes, and land use types for each parcel. 


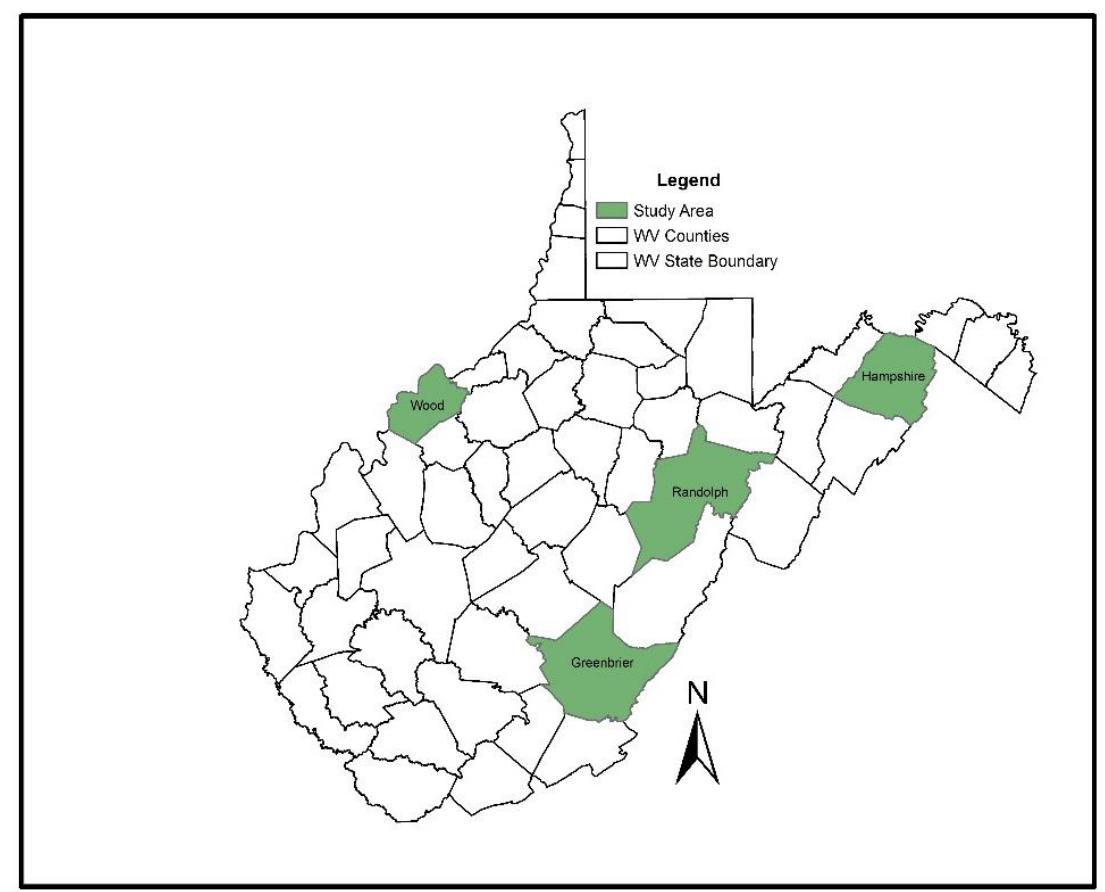

Figure 1. Counties selected to receive mail based questionnaire

Data released by the WVTD was sorted to include only parcels that included at least 10 acres of forested land. This acreage limit was set due to the minimum property size required for landowners to apply for several landowner incentive programs and suggests a minimum acreage where active management can occur.

A women woodland owner (WWO) sample population and a general woodland owner (GWO) sample population were selected from the tax data. Each parcel within a given county was assigned a random number. Random numbers were sorted from lowest to highest values. Women's names were selected from one end of the list for the WWO sample and all individual names were selected from the other end for the general woodland owners (GWOs) sample. This protocol served as a way to choose these two samples from the randomized list and to minimize the chance for duplicates in the sampled populations. Each of the resulting lists can be considered as two randomly drawn populations from the overall population of woodland owners 
of each county. Parcels were only chosen if they were associated with individuals' names, that is, individual owners assumed to be non-industrial, private forest owners (NIPF) and not associated with any corporation or public entity.

WWO names were chosen only if female names existed in the ownership. To increase the likelihood of contacting women woodland owners (WWOs), gender neutral names such as Pat, Terry, Chris and Lee were not chosen (Van Fleet \& Atwater, 1997). GWOs were selected without respect to gender. As in other states, the majority of property owners responding to woodland owner surveys in West Virginia have been male (Joshi \& Arano, 2009). Female joint owners are often represented by a respondent from the other sex to a much larger extent than are male joint owners (Leckie, 1996).

Once the initial WWO and GWO samples were selected, a careful examination was made to assure a landowner owning multiple properties had not been chosen twice. If a duplicate name or mailing address was found it was eliminated and replaced by the next landowner on the randomized list.

Three hundred woodland parcels, 150 WWOs and 150 GWOs, were selected from each of the four counties, for a total of 1200 parcels. This number of woodland owners forming the sample population was determined based on the goal to receive at least 30 full responses from each county/landowner group. Recent surveys using the WVTD data have resulted in response rates of just over 20\% (Joshi \& Arano, 2007; M. McCuen, D.W. McGill, K.A. Arano, and S.Owen, 2013; M. McCuen \& McGill, 2012; McGill, Grushecky, Moss, Pierskalla, \& Schuler, 2008). 


\section{Data collection instrument}

Two nearly identical questionnaires were developed for the target populations, i.e., WWOs and GWOs. For the GWOs, a questionnaire that was intended to be as "gender neutral" as possible was mailed out. This questionnaire contained identical questions to the WWO questionnaire, but featured a cover photograph that included males and females and was titled West Virginia Woodland Owner Needs Assessment, figure 2. An introductory paragraph described the study as an investigation into educational needs and management roles of woodland owners. A second questionnaire mailed to the WWO population contained a cover photo montage featuring photos of women performing woodland management activities and the title West Virginia Women Working in their Woods Woodland Owner Needs Assessment, figure 3. An introductory paragraph in the WWO questionnaire described that the research project was being conducted in order to investigate the management roles and educational preferences of women woodland owners.

Following institutional policies, once all the instruments for data collection were ready to send out these were presented along with the proposal for the study to the WVU Institutional Review Board for approval. An exempt approval was granted. 


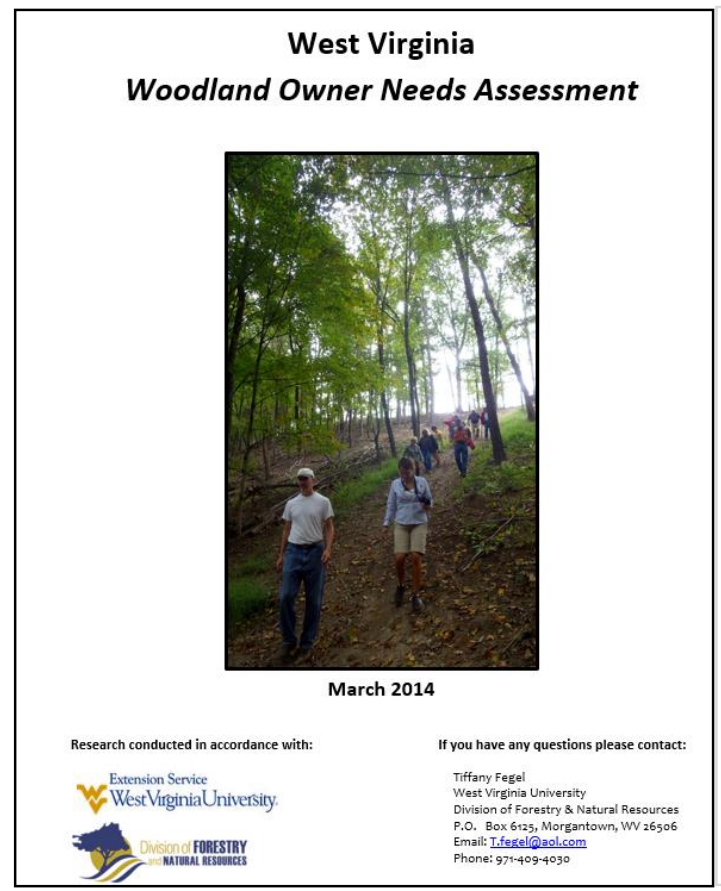

Introductory Paragraph: The purpose of this research is to assess the potential for extension outreach education opportunities for woodland owners in West Virginia. Nonindustrial private woodlands make up the majority of the landscape in the eastern United States making woodland owners an integral part in the management of West Virginia's forests. The goals of this project are to understand:

- the educational preferences of woodland owners;

- current management decisions, responsibilities, and actions occurring on properties;

Woodland is defined in this research as any parcel of land that is covered by trees.

Your participation is voluntary and you have the right to refrain from answering any questions. If you choose to participate, your answers will be kept confidential.

Thank you for your assistance with this important research!

Figure 2. GWO survey cover photo and introductory paragraph

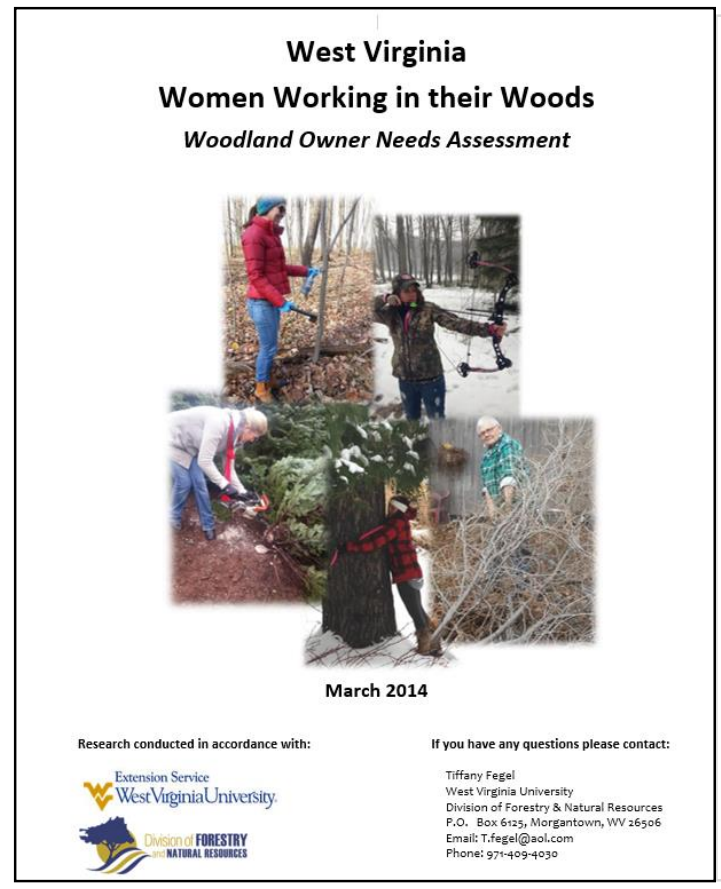

Introductory Paragraph: The purpose of this research is to assess the potential for extension outreach education opportunities for women woodland owners in West Virginia. Non-industrial private woodlands make up the majority of the landscape in the eastern United States. Women owners and co-owners comprise a large portion of this population. The goals of this project are to understand:

- current management decisions, responsibilities, and actions occurring on properties;

- the specific educational needs and preferences of women woodland owners.

Woodland is defined in this research as any parcel of land that is covered by trees.

Your participation is voluntary and you have the right to refrain from answering any questions. If you choose to participate, your answers will be kept confidential.

Thank you for your assistance with this important research!

Figure 3. WWO survey cover montage and introductory paragraph 
Both questionnaires contained questions in the following categories: woodland property ownership, woodland activities, management roles, interest in woodland topics, and demographics. Three major sections of the questionnaire were designed to elicit information related to management roles and educational preferences that would be used as "response" variables for testing for differences among male and female landowners.

The first section of the questionnaire was made up of different "management" activities that ranged from recreational walking to cutting trees. The management activities chosen were pulled from previous research (Allred, et al., 2011; Crim, et al., 2003; Leckie, 1996; Redmore, 2009). The second section of questions inquired about the respondents' preferences for various educational topics. The third section contained various seminar and time preference questions. The three sections were intended to form three separate response variables for testing differences among female and male woodland owners. Questions ranged from yes or no answers to four point Likert-type items. These questions were derived from previous research (Crim, et al., 2003; Effland, et al., 1993; Joshi \& Arano, 2007; M. McCuen, D.W. McGill, K.A. Arano, and S.Owen, 2013; Redmore, 2009; Redmore \& Tynon, 2011; Santos, Mitchell, \& Pope, 1999; Trauger, et al., 2008) and our research team.

Other questions were designed to serve as explanatory variables. The primary variable of interest was a binary measure for gender (female $=1$, male $=0$ ). In addition, the woodland property ownership section of the survey included questions such as property size, year of acquisition, type of ownership, residence status, the amount of contact participant had with forestry professionals, and timber production questions. These and other demographic questions were derived from previous studies (Joshi \& Arano, 2007; M. McCuen, D.W. McGill, K.A. Arano, and S.Owen, 2013; McGill, et al., 2008). All of these additional questions were aimed at 
determining whether gender, if it were deemed an important effect on management role or educational preference, had any interactions with other property ownership attributes.

In order to investigate management roles and answer research question number one, questions regarding the management activities that typically happen on NIPF properties were asked in an "I do this", "others do this, or "we do this" fashion (see figure 4).

15) Please indicate whether you or others undertake the following tasks. If both you and others do these,

\begin{tabular}{|c|c|c|c|c|}
\hline Activity & NA & $\begin{array}{l}\text { I do } \\
\text { this }\end{array}$ & $\begin{array}{l}\text { Others } \\
\text { do this }\end{array}$ & The others are: \\
\hline Sell timber & 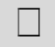 & $\square$ & $\square$ & \\
\hline Cut down trees & & $\square$ & $\square$ & \\
\hline Recreational walking & & $\square$ & $\square$ & \\
\hline Develop wildlife food/water sources & $\square$ & $\square$ & $\square$ & \\
\hline Trail/road maintenance & & $\square$ & $\square$ & \\
\hline Cut firewood & $\square$ & $\square$ & $\square$ & \\
\hline Talk with neighbors about woodland issues & $\square$ & $\square$ & $\square$ & \\
\hline Tree trimming/maintenance & $\square$ & $\square$ & $\square$ & \\
\hline Fence construction/maintenance & $\square$ & $\square$ & $\square$ & \\
\hline Prepare taxes & $\square$ & $\square$ & $\square$ & \\
\hline Other: & $\square$ & $\square$ & $\square$ & \\
\hline
\end{tabular}

Figure 4. Question related to management activities used as response variables for testing differences by gender.

Research question number two addresses the educational preferences of women woodland owners. In order to do so, a series of Likert scale items were asked regarding topics as well as formats of preference for woodland owners.

Five short answer (open-ended) questions were also included throughout the questionnaire. These qualitative statements were inserted to help define more accurately landownership attributes of interest. Open-ended questions can have an advantage over multiple choice questions for exploring new meaning of phenomena of interest by allowing respondents 
to answer a question in their own words (Crawford, 1997). They have the ability to extract unbiased and unrestricted information from participants that can be invaluable to research (Culp \& Pilat, 1998; Santos, et al., 1999). These short answer questions pertained to landowner objectives, management roles, and woodland appreciation.

The questionnaire was reviewed for content validity by a panel of 30 undergraduate students as part of a recreation class at West Virginia University. Each member of this panel, 22 men, and 8 women, took the questionnaire as if they were woodland owners. A 30 minute review and discussion of the questionnaire took place once all panel members had finished. As a result of this we added two questions directly related to gender in forest outreach education (question number 21 and 22 below). Many panel members suggested this in order to get a better direct understanding of survey participant's feelings regarding gender issues.

21) I would feel most comfortable at a workshop with: (Check one)

__ Mostly women

__ Mostly men

__ Mixture of both

22) Have you ever felt that your experience at a seminar has been affected by your gender? Please describe:

A pilot survey was sent to test validity and readability. This group was composed of 4 West Virginia Woodland owners, 2 consulting foresters, 5 West Virginia University Division of Forestry and Natural Resources faculty members, and 5 West Virginia University Division of Forestry and Natural Resources graduate students. Following this process the phrasing and 
layout of many of the questions were altered to increase the likelihood of receiving valid and reliable responses.

The mailing process included a multi-step approach following the protocol recommended by Dillman (1978). A pre-survey postcard was mailed out on March 5, in order to inform landowners they should be expecting a survey. Following the postcard, the questionnaire was mailed out on March 13, including a cover letter explaining the purpose, goals, and intended use of the survey. A postcard reminding landowners to return the survey was mailed out 8 days after the survey on March 21. For those who did not respond, a final mailing was sent May 1, and included a letter reminding non-respondents the importance of their participation and an additional copy of the survey.

\section{Comparison of WWO and GWO educational needs and management roles}

Using gender as an explanatory variable, we tested for differences in the response variables of interest related to educational preferences and management roles. With the goal of finding associations in the data, Statistical Analysis Software (SAS) was used to run logistic regressions and principal component analysis (SAS, 2011).

For data analysis purposes women respondents from the GWO questionnaire were combined with the women respondents in the WWO population. This allowed us to analyze women woodland owners and co-owners as a whole. 


\section{Variable reduction process}

Likert scale questions were used to explore two associations 1) woodland owners' educational preferences 2) woodland owners preferred formats of educational outreach opportunities. Participants chose whether they were 'not likely, somewhat likely, likely, or very likely' to attend workshops with specified topics. They chose 'not interested, somewhat interested, interested, or very interested' in attending workshops with given formats.

A series of management activities listed in an 'I do, they do, we do' format (figure 4) was utilized to quantify management roles and as a response (dependent) variable. The two sets of Likert scale questions regarding education outreach topics and formats were also used as response variables to describe landowners educational preferences.

Principal Component Analysis (PCA) was used to examine the two sets of Likert questions to reduce the number of variables into indices that could be used for analysis. PCA is a method that uses orthogonal transformation to reduce a large number of correlated variables into a smaller set of composite variables. The goal of using this variable reduction process is to produce composite variables for each group with a minimum loss of information.

The protocol in the variable reduction step first examined Spearman rank correlations in PROC CORR to assess opportunities for variable reduction, since it was expected many of these scaled items would be strongly correlated. The degree of correlations among the variable sets is an indication that the variables have some redundancy (Stevens, 1992). Using PROC FACTOR METHOD=ML HEYWOOD, Bartlett's of sphericity was used to test the significance of the correlations. This tests null hypotheses that: 1) there are no common factors, and 2) one factor is enough, meaning that if we reject the null hypothesis of no common factors this suggests that at least some of the variables are correlated. In order to quantify the degree of correlation among 
the variables we used Kaiser's measure of Sample Adequacy (MSA). When MSA is greater than 0.50 the level of acceptability is met. If overall MSA is 1.0 the variables are perfectly predicted from the other variables.

PCA was then used to evaluate the variation in correlation matrices of the variables for underlying components. PCA was carried out using the FACTOR procedure and the METHOD=PRINCOMP in SAS 9.3 (SAS, 2011). The selection of components used several methods, but relied primarily on the results of parallel analysis (Patil, Singh, Mishra, \& Donavan, 2008). Parallel analysis compares the 95th percentile of eigenvalues from random correlation matrices with correlation matrices of interest, that is, those in this study. A SAS program developed by O'Connor (2000) was used to carry out the parallel analysis. Finally, variables loading on a given component were tested for internal consistency (how similar they are) with Cronbach's $\alpha$, generated in the CORR procedure in SAS. Groups of variables (questionnaire items) with Cronbach's $\alpha$ greater than or equal to 0.70 were then used in Likerttype scales by taking the average values of the items.

Likert items were combined into two groups including "not interested" and "more interested" with the dividing line for these two categorizations being the median of the responses. 


\section{Chapter 4: Results}

\section{Questionnaire response rates}

Of the 1200 surveys that were distributed a total of 305 completed surveys were returned yielding a response rate of $25 \%$ and a cooperation rate, defined as "the proportion of all cases interviewed of all eligible units ever contacted" (AAPOR, 2011, p. 5) of 68\%. One hundred thirty-seven surveys were returned blank, 66 surveys were returned due to bad addresses and 10 were deemed ineligible due to not owning land or the landowner having passed away.

\section{Demographics}

Fifty percent of respondents were male (see Table 1). Eighty-six percent of the respondents were over the age of 50, and 61 percent had at least an Associate's degree. The majority of respondents made at least forty-five thousand dollars a year. 
Table 1. Woodland owner characteristics by gender.

\begin{tabular}{|c|c|c|}
\hline \multicolumn{3}{|l|}{ Owner characteristics } \\
\hline & Male & Female \\
\hline & $(\%)$ & $(\%)$ \\
\hline Gender & 51 & 49 \\
\hline \multicolumn{3}{|l|}{ Age } \\
\hline $18-30$ & 1 & 1 \\
\hline $30-40$ & 4 & 2 \\
\hline $40-50$ & 9 & 10 \\
\hline $50-60$ & 36 & 23 \\
\hline $60-70$ & 28 & 35 \\
\hline $70+$ & 22 & 30 \\
\hline \multicolumn{3}{|l|}{ Education } \\
\hline Some high school & 3 & 4 \\
\hline High school graduate & 13 & 22 \\
\hline GED & 1 & 1 \\
\hline Trade School & 6 & 7 \\
\hline Some college & 16 & 19 \\
\hline Associates degree & 9 & 4 \\
\hline Bachelor's degree & 29 & 19 \\
\hline Master's degree & 18 & 18 \\
\hline Ph.D & 5 & 4 \\
\hline \multicolumn{3}{|l|}{ Income } \\
\hline Less than $\$ 15,000$ & 13 & 3 \\
\hline$\$ 15,001-\$ 30.000$ & 14 & 12 \\
\hline$\$ 30,001-\$ 45,000$ & 9 & 21 \\
\hline$\$ 45,001-\$ 60,000$ & 18 & 11 \\
\hline$\$ 60,001-\$ 75,000$ & 10 & 14 \\
\hline$\$ 75,001-\$ 90,000$ & 10 & 10 \\
\hline$\$ 90,000+$ & 26 & 29 \\
\hline
\end{tabular}

\section{Management roles}

Comparative graphs utilizing gender as the descriptive variable are presented below describing whether the landowner themselves do certain woodland management activities, if others do listed activities, or if 'we' (participant and others) do said activities. Figure 5 shows that almost 90 percent of males say that they cut down trees and over 80 percent of females say 
that others complete this task. Figure 6 displays a similar result with more men saying they do most of the communication with neighbors and more women saying others do this activity. In every category given this was the case. Figure 7 shows responses for recreational walking, one of two categories that had closer results (the other being tax preparation) in which nearly the same amount of males and females stated "I do", "They do", and "We do."

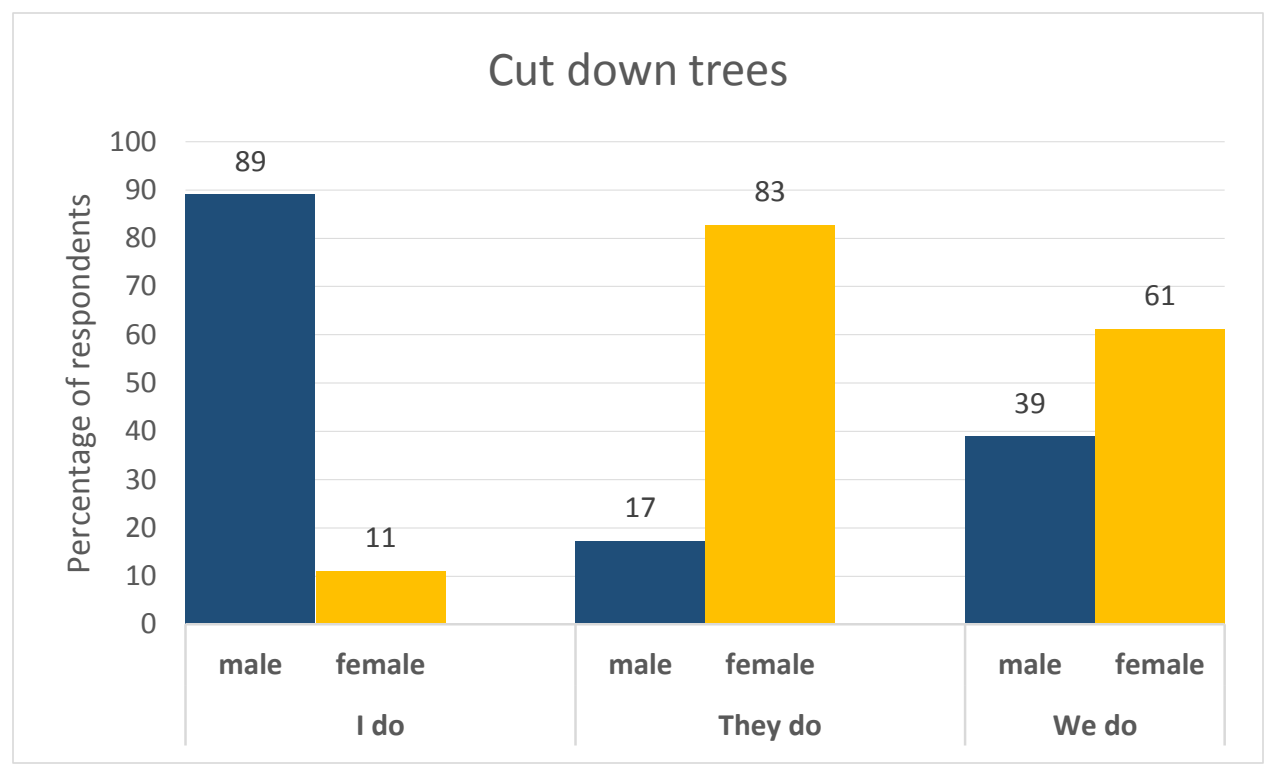

Figure 5. Percentage of respondents designating those who "cut down trees" by gender. 


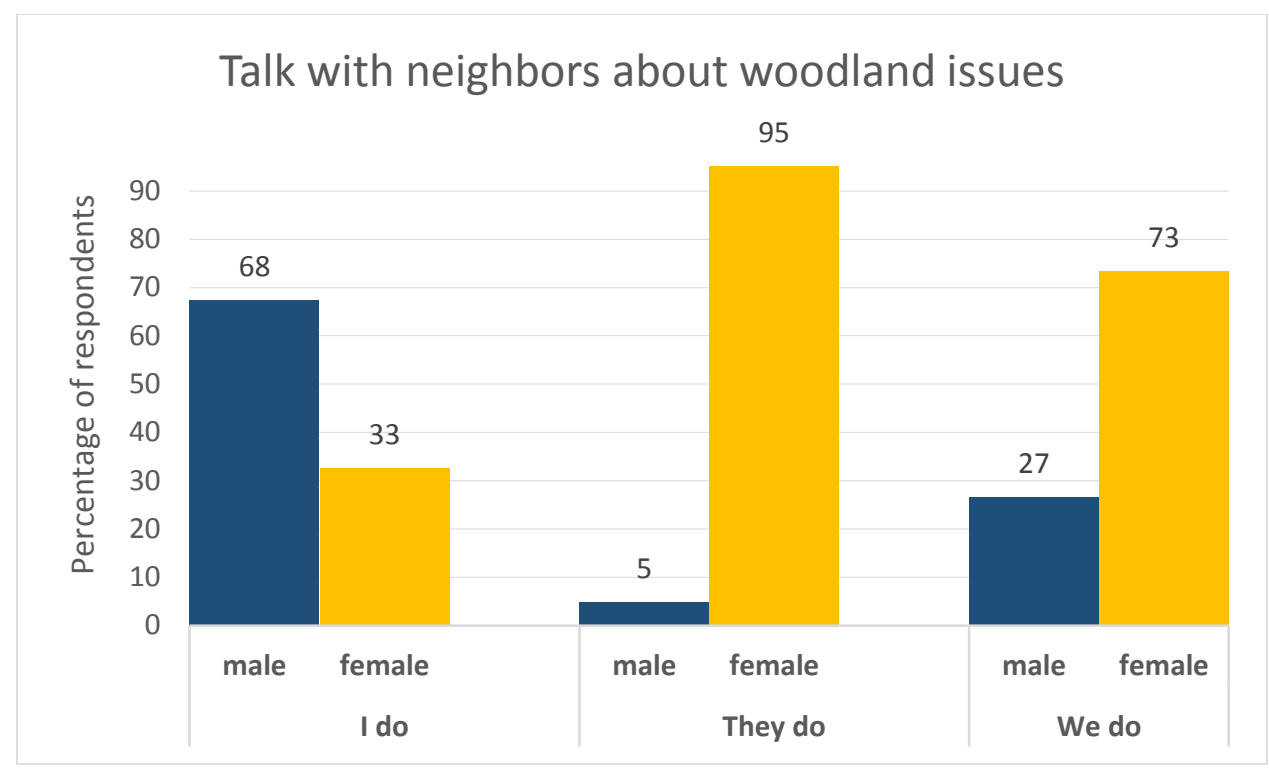

Figure 6. Percentage of respondents designating those who "talk with neighbors about woodland issues" by gender.

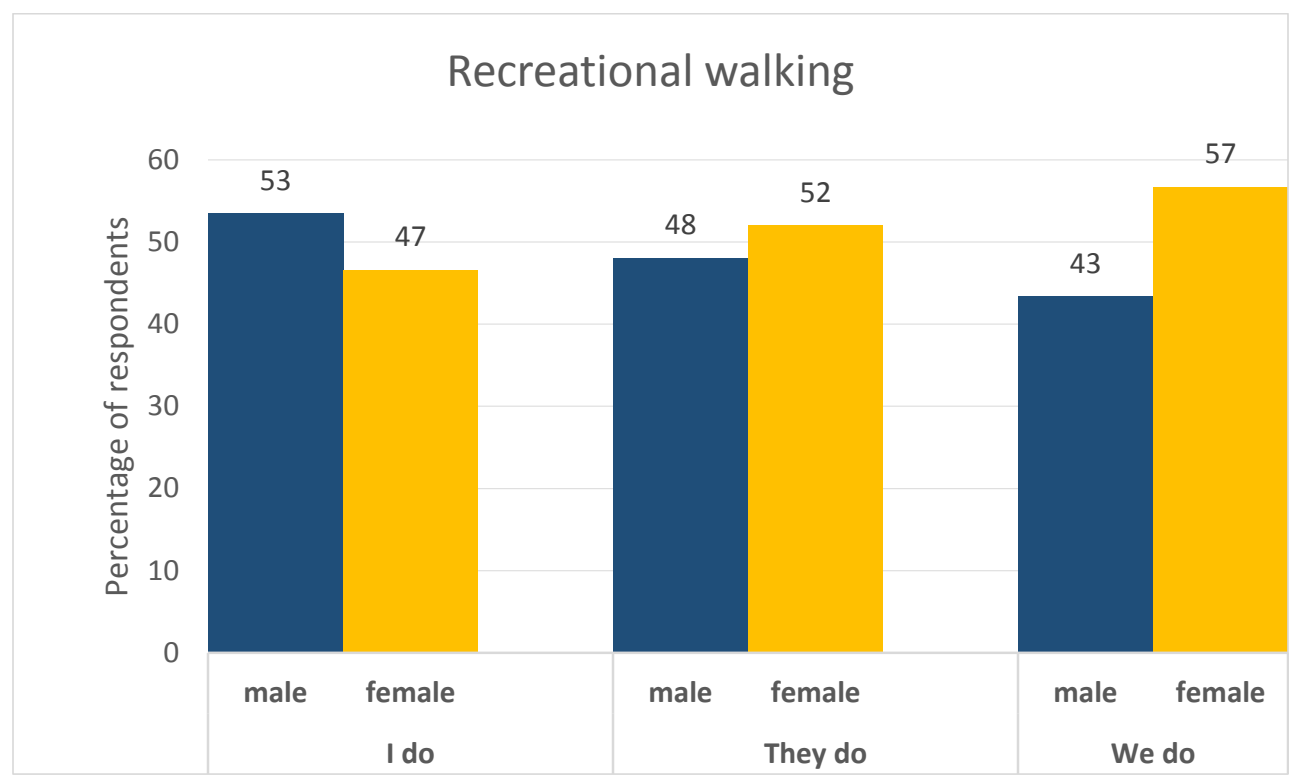

Figure 7. Percentage of respondents designating those who do "recreational walking" on property by gender.

Variables associated with management activities and demographic characteristics in a binary form were also used as explanatory variables to measure correlations between these variables and response variables, Table 2. 
Table 2. Logistic regression analysis of management activities modeled as a binary response where $1=I /$ We do this, $0=$ Others do this. Odds ratios (above) and probability ( $p$-values) for Wald $\chi^{2}$ test (below in italics) are given for explanatory variables in each model.

\begin{tabular}{|c|c|c|c|c|c|c|}
\hline $\begin{array}{l}\text { Response } \\
\text { variables } \\
\text { (Mgt. activities) } \\
\end{array}$ & Intercept & Gender & Residency & $\begin{array}{c}\text { Harvested } \\
\text { Timber } \\
\end{array}$ & $\begin{array}{c}\text { Property } \\
\text { Size } \\
\end{array}$ & Education \\
\hline Sell timber & $<0.001$ & $\begin{array}{c}0.170 \\
<0.001 *\end{array}$ & $\begin{array}{l}1.004 \\
0.860\end{array}$ & $\begin{array}{c}0.031 \\
<0.001 *\end{array}$ & $\begin{array}{l}1.001 \\
0.369\end{array}$ & $\begin{array}{l}1.112 \\
0.226\end{array}$ \\
\hline Cut down trees & 0.025 & $\begin{array}{c}0.112 \\
<0.001 *\end{array}$ & $\begin{array}{l}0.990 \\
0.460\end{array}$ & $\begin{array}{l}0.699 \\
0.279\end{array}$ & $\begin{array}{l}0.999 \\
0.240\end{array}$ & $\begin{array}{l}0.943 \\
0.371\end{array}$ \\
\hline $\begin{array}{l}\text { Recreational } \\
\text { walking }\end{array}$ & 0.301 & $\begin{array}{l}0.791 \\
0.444\end{array}$ & $\begin{array}{l}0.977 \\
0.055\end{array}$ & $\begin{array}{l}1.185 \\
0.601\end{array}$ & $\begin{array}{l}1.000 \\
1.000\end{array}$ & $\begin{array}{l}1.052 \\
0.430\end{array}$ \\
\hline $\begin{array}{c}\text { Develop } \\
\text { wildlife } \\
\text { food/water } \\
\text { sources }\end{array}$ & 0.226 & $\begin{array}{c}0.234 \\
<0.001 *\end{array}$ & $\begin{array}{l}0.992 \\
0.531\end{array}$ & $\begin{array}{l}0.741 \\
0.340\end{array}$ & $\begin{array}{l}1.002 \\
0.071\end{array}$ & $\begin{array}{l}0.925 \\
0.209\end{array}$ \\
\hline $\begin{array}{c}\text { Trail/road } \\
\text { maintenance }\end{array}$ & 0.577 & $\begin{array}{c}0.194 \\
<0.001 *\end{array}$ & $\begin{array}{l}0.999 \\
0.928\end{array}$ & $\begin{array}{l}1.464 \\
0.220\end{array}$ & $\begin{array}{l}1.002 \\
0.115\end{array}$ & $\begin{array}{l}1.072 \\
0.266\end{array}$ \\
\hline Cut firewood & 0.021 & $\begin{array}{c}0.189 \\
<0.001 *\end{array}$ & $\begin{array}{l}0.986 \\
0.297\end{array}$ & $\begin{array}{l}0.867 \\
0.647\end{array}$ & $\begin{array}{l}0.998 \\
0.128\end{array}$ & $\begin{array}{l}0.920 \\
0.178\end{array}$ \\
\hline $\begin{array}{c}\text { Talk with } \\
\text { neighbors about } \\
\text { woodland issues }\end{array}$ & 0.236 & $\begin{array}{c}0.481 \\
0.008 *\end{array}$ & $\begin{array}{l}1.016 \\
0.190\end{array}$ & $\begin{array}{l}1.069 \\
0.823\end{array}$ & $\begin{array}{l}1.001 \\
0.275\end{array}$ & $\begin{array}{l}1.090 \\
0.148\end{array}$ \\
\hline $\begin{array}{c}\text { Tree } \\
\text { trimming/maint. }\end{array}$ & 0.882 & $\begin{array}{c}0.235 \\
<0.001 *\end{array}$ & $\begin{array}{l}1.014 \\
0.240\end{array}$ & $\begin{array}{l}1.048 \\
0.879\end{array}$ & $\begin{array}{l}1.000 \\
0.948\end{array}$ & $\begin{array}{l}1.079 \\
0.214\end{array}$ \\
\hline $\begin{array}{c}\text { Fence } \\
\text { construction/ } \\
\text { maintenance }\end{array}$ & 0.131 & $\begin{array}{c}0.266 \\
<0.001 *\end{array}$ & $\begin{array}{l}0.992 \\
0.544\end{array}$ & $\begin{array}{l}0.632 \\
0.136\end{array}$ & $\begin{array}{l}1.001 \\
0.343\end{array}$ & $\begin{array}{l}0.954 \\
0.440\end{array}$ \\
\hline Prepare taxes & 0.293 & $\begin{array}{l}0.602 \\
0.065\end{array}$ & $\begin{array}{l}1.007 \\
0.543\end{array}$ & $\begin{array}{c}0.851 \\
0.584\end{array}$ & $\begin{array}{l}1.000 \\
0.736\end{array}$ & $\begin{array}{l}1.051 \\
0.398\end{array}$ \\
\hline
\end{tabular}

*indicates statistical significant difference 
At a significance level of .05 there are significant differences in gender for the variables selling timber, cutting trees, developing wildlife food/water sources, trail and road maintenance, cutting firewood, tree trimming/maintenance, talking with neighbors about woodland issues, and fence construction.

Generally female respondents were less likely to answer that they took part in one of the ten management activities listed in the questionnaire. For example, the odds of a female respondent answering that she takes part in selling timber is only $17 \%$ of the odds of a male respondent. The only management activity that was not statistically different between male and female respondents was recreational walking (gender $\mathrm{OR}=0.791 ; \mathrm{p}=0.444)$. Importantly, this finding does not clearly infer that men do more of these activities than women, only that the female respondent herself has lower odds of answering that she takes part in them.

Only one other factor was statistically related to the management activity response variables. Respondents who had not harvested timber in the past had only 3 percent of the odds of saying they actively participated in timber sales as those who had harvested timber in the past (timber sales $\mathrm{OR}=0.031 ; \mathrm{p}=0.001)$.

\section{Educational Preferences}

Educational formats and educational topics were the two sections of the questionnaire containing Likert items designed to represent the educational needs and preferences of woodland owners.

\section{Educational Topics}

Principal component analysis was utilized as a means for variable reduction to describe the topics of interest to woodland owners. 
In order to determine the number of components to describe the data we used the process of parallel analysis (Hair, Anderson, Tatham, \& Black, 1998). Parallel analysis generates a $95^{\text {th }}$ percentile set of eigenvalues (figure 8) from a set numbers of randomly generated correlation matrices. Eigen values which exceed this $95^{\text {th }}$ percentile are thought to be from populations that vary in other than a random way.

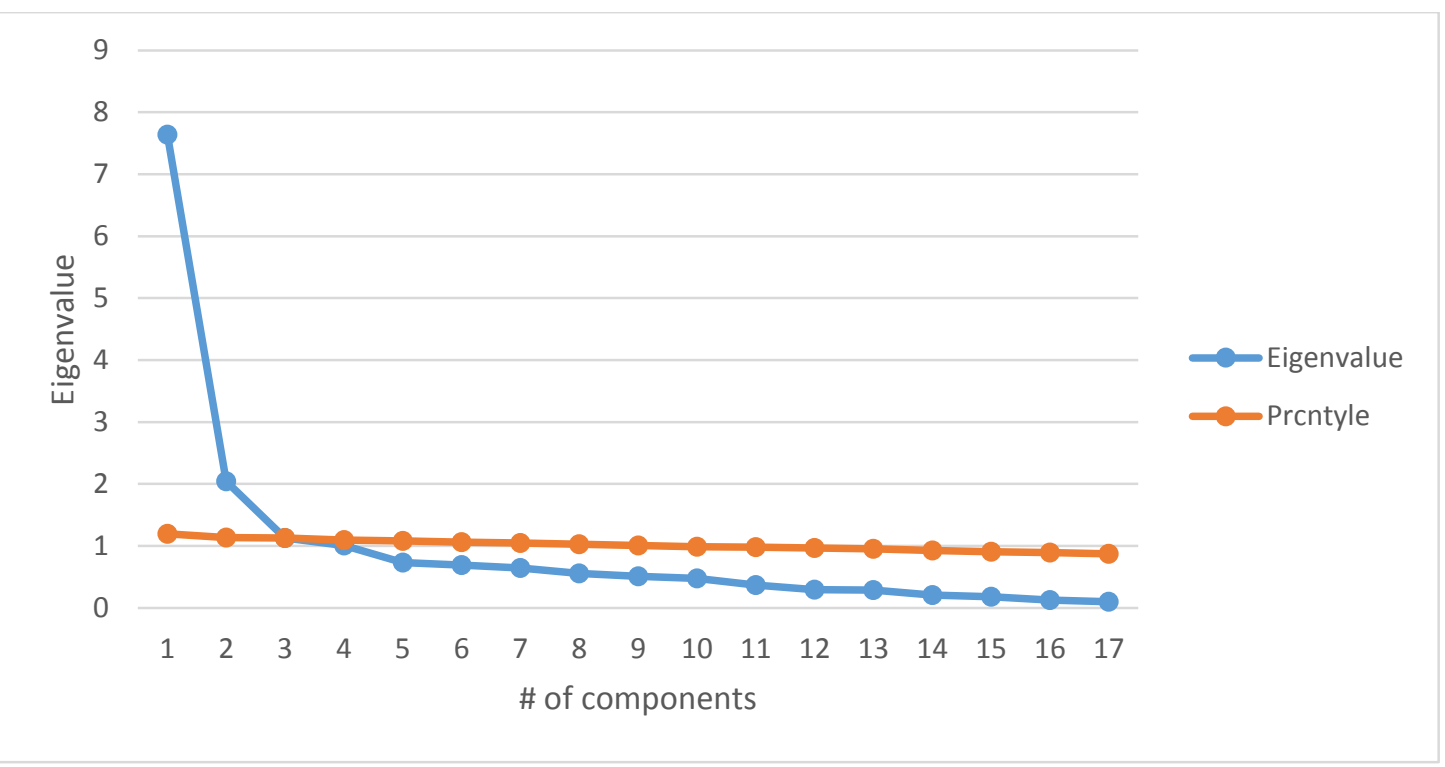

Figure 8. Parallel analysis for topics of interest showing eigenvalues of components 1-17 from woodland owner questionnaire data and corresponding eigenvalues at the $95^{\text {th }}$ percentile of values generated from random populations.

Cronbach's Alpha was generated for variables that grouped on a given component to check the internal consistency, the degree to which a set of items is explained by a single latent factor or in this case, a component. Following the parallel analysis we ran the PCA requesting two components as the eigenvalues suggested.

The two principal components were designated as timber management and nature appreciation (Table 3). These two components accounted for 85 percent of the variation in this group of Likert items. The nature component is a summated scale of the following variables; medicinal herbs, using equipment, wildlife identification, and bird watching/identifying. The 
timber management component is a summated scale of the following variables: timber harvest, marketing timber, how to measure timber value, creating more productive timber lands, and land transfer. These components were named to reflect attributes of the variables that had the highest loadings and that would adequately describe the group of variables as a whole.

Ideally all of the variables load onto the principal components. However, this data had high levels of loading for some variables on multiple components, referred to as crossloading. This could have been for numerous reasons including that the terms were vague and left up to interpretation to the participant, i.e. non timber forest products. Also, some of these variables could have been equally important to both groups, i.e. stewardship, and state incentive programs.

In order to better understand these crossloading variables (trapping and hunting wildlife, managing for wildlife, creating deer habitat, state incentive programs, stewardship, forestry terminology, and non-timber forest products) and more precisely analyze the components that were not crossloading we eliminated variables that had significant crossloadings. There exists no standard method to judge the significance of crossloading assessment (Matsunaga, 2010). In this data reduction process, if the lowest loading on a particular variable was more than half of the higher loading then we eliminated it. These crossloaded variables were then analyzed separately. Two groups were formed from this process, game management and terminology. Game management consisted of the following variables; trapping and hunting wildlife, Managing for wildlife, and creating deer habitat. Terminology included; state incentive programs, stewardship, forestry terminology, and non-timber forest products.

We used generated descriptive statistics that we then converted to binary response variables out of the Likert items. Factors that are more or less associated with interest levels for 
the various topics were of higher interest to this research. In order to establish these values variables were broken into higher interest and lower interest categories based on the respective medians for each topic, in which half the observations are above the median (more interested) and half are below (less interested).

Table 3. Survey items assessing likelihood of attending workshops with given topics and descriptive statistics for principal components analysis. Each topic item was a Likert-type scale from 1 (not likely) to 4 (very likely). Two principal components $(P C)$ were identified. Cronbach's $\alpha$ is a measure of internal consistency of items within a given component used to examine the appropriateness of combining items into summated scales.

\section{Survey item:}

I would like to

Mean (sd) participate in a workshop regarding...

...Timber harvest $1.91 \quad 1.04$

0.88

1

0.85

Timber man.

... Marketing timber

1.70

0.96

0.86

1

Timber man.

... How to measure timber value

$2.02 \quad 1.05$

0.83

1

Timber man.

... Creating more productive timber lands

$1.90 \quad 1.04$

0.77

1

Timber man.

....Land transfer

1.46

0.84

0.49

1

Timber man.

... Medicinal herbs

2.32

1.13

0.81

2

0.84

Nature app.

... Forest grown mushrooms

$2.14 \quad 1.15$

0.73

2

Nature app.

... Using equipment

1.62

0.96

0.51

2

Nature app.

...Identifying wildlife

2.14

1.06

0.88

2

Nature app.

... Bird watching/identifying

$1.99 \quad 1.16$

0.86 2

Nature app.

Female respondents were found to be less likely than male respondents to carry out timber harvesting and wildlife management activities. Female respondents had only about half 
the odds of male respondents in saying they participate in timber management activities

$(\mathrm{OR}=0.58 ; \mathrm{p}=0.044)$ and wildlife management activities $(\mathrm{OR}=0.51 ; \mathrm{p}=0.011)$, table 4 .

Table 4. Logistic regression analysis of educational topics modeled as a binary response where $1=$ more likely to attend, $0=$ less likely to attend. Odds ratios (above) and probability ( $p$-values) for Wald $\chi^{2}$ test (below in italics) are given for explanatory variables in each model.

\begin{tabular}{|lcccccc|}
\hline $\begin{array}{l}\text { Response } \\
\text { variables } \\
\text { (Topics) }\end{array}$ & Intercept & Gender & Residency & $\begin{array}{c}\text { Harvested } \\
\text { Timber }\end{array}$ & $\begin{array}{c}\text { Property } \\
\text { Size }\end{array}$ & Education \\
\hline & & & & & & \\
Timber & 0.603 & 0.582 & 1.002 & 0.682 & 1.003 & 1.047 \\
management & 0.044 & 0.830 & 0.191 & 0.038 & 0.428 \\
Nature & & & & & & \\
appreciation & 0.349 & 0.100 & 0.907 & 0.616 & 0.920 & 0.630 \\
Game & & 0.54 & 1.0 & 1.06 & 1.0 & 0.96 \\
management & 0.437 & 0.011 & 0.892 & 0.838 & 0.508 & 0.504 \\
Terminology & 0.789 & 0.80 & 0.99 & 0.90 & 1.00 & 1.07 \\
& & 0.415 & 0.322 & 0.704 & 0.030 & 0.281 \\
\hline
\end{tabular}

\section{Educational formats}

To analyze preferred educational formats we used a similar procedure as topics starting with a Spearman correlation test, followed by Barlett's test of sphericity, MSA, and parallel analysis. However, variables from the Likert items only loaded on to one component as suggested by the parallel analysis (Figure 9). 


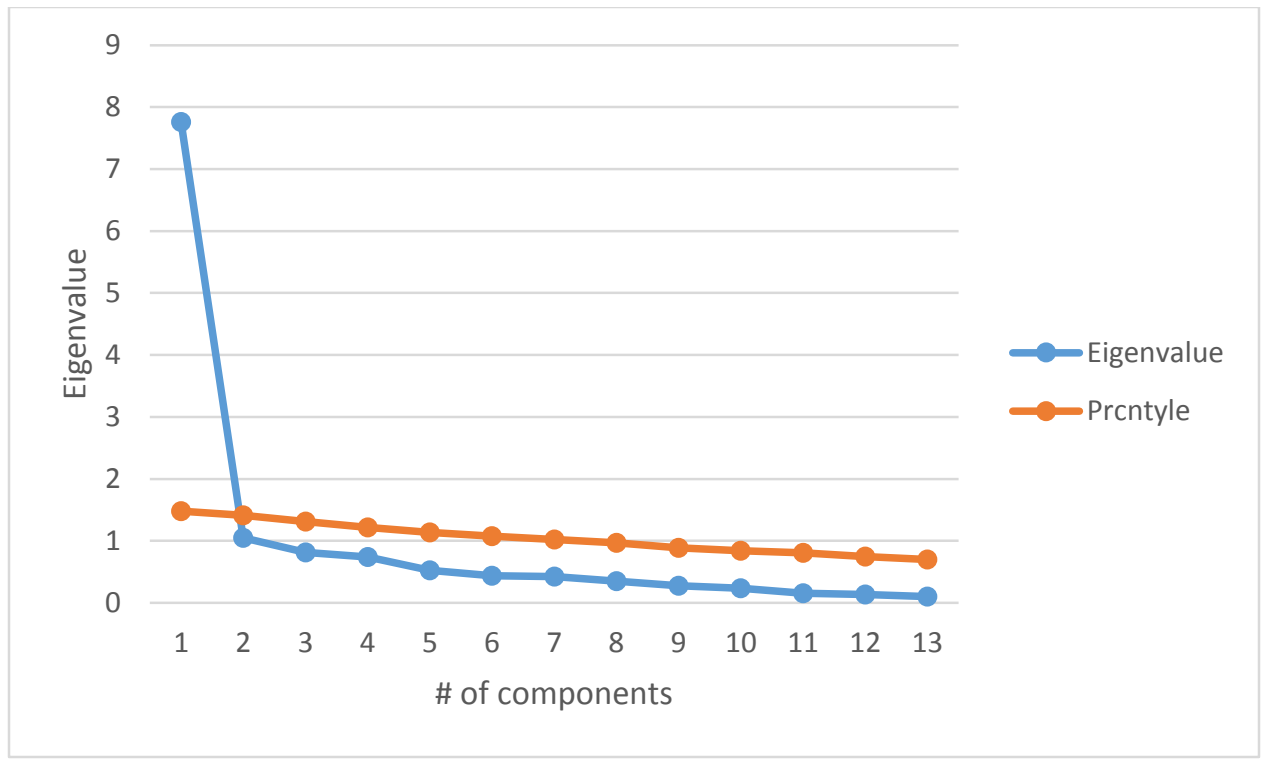

Figure 9. Parallel analysis for educational formats showing eigenvalues of components 1-13 from woodland owner questionnaire data and corresponding eigenvalues at the $95^{\text {th }}$ percentile of values generated from random populations.

The original 13 Likert items related to educational formats were paired down to nine because four of the items had low communality. Communality is the amount of variation accounted for by the 'factor solution' for each variable. Generally, variables with less than 50 percent communality do not have sufficient explanation. Hair et al. (1998) suggests that when this happens there are two options: 1) interpret and ignore low variables, or 2) examine the significance of variables to the research and communality score and consider for deletion. The second option was chosen and each of the variables were analyzed on their own after removing them from the PCA. The four eliminated items, PowerPoint presentations, online webinar, event for families (including children's activities), and weekday evening workshop, were tested for internal consistency to see if they could be their own group, however, the Cronbach's alpha for this group was only 0.68 , lower than the 0.70 cut off. Each of the eliminated variables were used as binary response variables in logistic regression models (Table 6). 
A summated scale was generated by taking the average response for a single respondent of the variables that loaded on a given component. The summated scale of the interactive component included the variables weekend workshop meeting hosted in the woods of a woodland owner, indoor meeting with natural resource professionals, discussion with other forest owners, event with instructors who are my same gender, discussion with natural resource professionals, demonstration in the forest, weekday evening workshop, and question and answer session(Table 5). The Cronbach's alpha for this grouping was very high at 0.94 . The interactive component was made into a binary variable by dividing the observations into two groups:those above the median represented those that are more interested in attending workshops using these formats and below the median represented those who are less interested. We then ran a logistical regression on this component in order to test its association with the response variables, table 6 .

Table 5. Survey items assessing interest in attending workshops using given formats and descriptive statistics for principal components analysis. Each topic item was a Likert-type scale from 1 (not likely) to 4 (very likely).

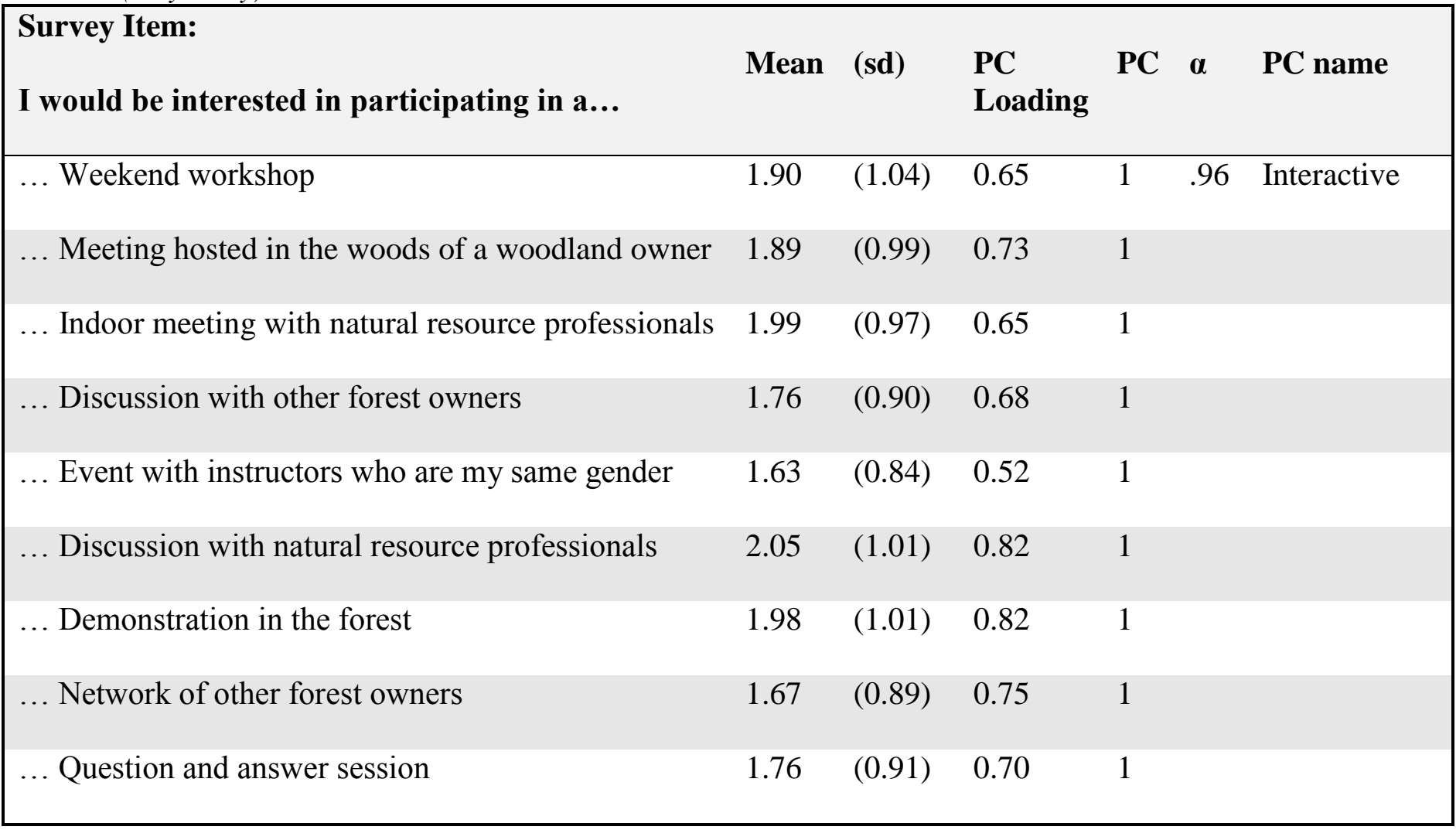


There were no significant differences in gender from the results of the educational topics section of the survey, table 6. Significant differences were found relating levels of education to family events and interactive event.

Table 6. Logistic regression analysis of educational formats modeled as a binary response where $1=$ more likely to attend, $0=$ less likely to attend. Odds ratios (above) and probability ( $p$-values) for Wald $\chi^{2}$ test (below in italics) are given for explanatory variables in each model.

\begin{tabular}{|c|c|c|c|c|c|c|}
\hline $\begin{array}{l}\text { Response } \\
\text { variables } \\
\text { (Format) } \\
\end{array}$ & Intercept & Gender & -------Exp & $\begin{array}{l}\text { anatory vari } \\
\text { Harvested } \\
\text { Timber }\end{array}$ & $\begin{array}{l}\text { bles---:--.- } \\
\text { Property } \\
\text { Size } \\
\end{array}$ & Education \\
\hline Interactive & 0.4774 & $\begin{array}{c}0.87 \\
0.6037\end{array}$ & $\begin{array}{c}0.94 \\
0.7477\end{array}$ & $\begin{array}{c}0.91 \\
0.5347\end{array}$ & $\begin{array}{c}1.00 \\
0.7470\end{array}$ & $\begin{array}{c}1.12 \\
0.0456\end{array}$ \\
\hline PowerPoint & 0.991 & $\begin{array}{c}1.29 \\
0.348\end{array}$ & $\begin{array}{c}1.00 \\
0.911\end{array}$ & $\begin{array}{c}1.00 \\
0.263\end{array}$ & $\begin{array}{c}.726 \\
0.611\end{array}$ & $\begin{array}{c}.917 \\
0.134\end{array}$ \\
\hline Webinar & 0.080 & $\begin{array}{l}1.125 \\
0.650\end{array}$ & $\begin{array}{l}0.969 \\
0.346\end{array}$ & $\begin{array}{l}1.294 \\
0.361\end{array}$ & $\begin{array}{c}1.00 \\
0.695\end{array}$ & $\begin{array}{l}0.983 \\
0.764\end{array}$ \\
\hline Family Event & 0.732 & $\begin{array}{c}1.00 \\
0.993\end{array}$ & $\begin{array}{c}0.96 \\
0.445\end{array}$ & $\begin{array}{c}0.93 \\
0.801\end{array}$ & $\begin{array}{c}1.00 \\
0.106\end{array}$ & $\begin{array}{c}0.89 \\
0.047\end{array}$ \\
\hline $\begin{array}{l}\text { Weekday } \\
\text { Evening }\end{array}$ & 0.794 & $\begin{array}{c}1.18 \\
0.541\end{array}$ & $\begin{array}{c}0.80 \\
0.396\end{array}$ & $\begin{array}{c}0.69 \\
0.188\end{array}$ & $\begin{array}{c}1.00 \\
0.110\end{array}$ & $\begin{array}{c}0.96 \\
0.478\end{array}$ \\
\hline
\end{tabular}




\section{Chapter 5: Discussion}

The most significant findings of this research came from the management roles section of the survey. Of the 10 items used to measure activity in various management roles, 8 were statistically significant related to gender. In regards to these 8 listed activities related to management activities, more women said that others did the activities while men generally said they themselves completed the activity. This could likely be related to role theory as it relates to forestry in that many of the management activities that we listed were not 'typical' activities for women. The two that may be perceived as socially more acceptable for women, recreational walking, and preparing taxes, were the two that did not show statistically significant differences between gender. Trauger et al. (2008) discussed this as a gendered division of labor and that women identify themselves as support roles that can only participate in certain management activities.

Previous research has found that women are more likely to manage their woodlands for things like wildlife and non-timber forest products (Crim, et al., 2003) and would therefore be more likely to attend workshops regarding these topics. Previous research also indicates that women prefer peer learning and discussions as opposed to top down modes of education (Crim, et al., 2003). This research found no statistical differences by gender in preferred educational formats. The difference in findings from this research to others may be due to the methodology of this survey, as in utilizing a direct comparison survey, and/or the utilization of principal component analysis which groups the variables that individually (possibly used this way in other surveys) could have shown differences. Also, utilizing a direct gender comparison study in forestry educational preferences is not something that has been done before (that these 
researchers could find). It could be that woodland owners in general prefer certain educational formats for obtaining forest knowledge.

It was found that women stated that they would be less likely to come to educational events that focused on timber management (42 percent) and nature appreciation (49 percent). Because timber management and nature appreciation were made up of multiple topics and no previous research found has specifically addressed similar grouping. Many previous studies have looked at individual topics that make up the groups in this study, for instance, previous research has stated that women may be less likely to participate in timber management (Redmore, 2009) and to have greater standing timber volume (Lidestav and Ekstrom, 2000). Aesthetics and the beauty of nature tend to be one of the highest reasons for woodland ownership (Butler, 2008) and the slight difference between men and women found in this study may be due to one of the topics linked to nature appreciation. None of the four educational topic groups in this research were found to be of statistically greater interest to women than men.

The perception that women do not belong in woodland management roles (Crim, et al., 2003; Redmore, 2009) could be related to the theory of empowerment. This research did not specifically gauge women's perception of if they belong in these roles, but our results do show a number of women saying they do not participate in woodland management activities. Whether this is the result of perceived barriers was not investigated in this study, but should be in future studies. As pointed to by Trauger (2008), the discussion and education of women regarding skills typically associated with being a male in a forestry role could result in the "agency and empowerment of women" (Trauger, et al., 2008). With this knowledge and empowerment women may not feel as inferior in their forestry roles. Future work could focus on the barriers women face in forestry and whether education is truly one of those barriers. Specific questions 
regarding why women do not participate in forest management activities i.e. time limitations, physical limitations, family obligations, etc. would be able to shed light on this question.

The results of this study indicated a low interest in coming to workshops in general. The low interest in attending workshops could be addressed in a similar way. Since we now know that women are, in general, less likely to come to any type of workshop, future research could try to understand why this is utilizing similar questions as to why women do not participate in forest management activities.

Based on previous studies, peer learning networks would be a beneficial way to empower women through education. Over half $(51 \%)$ of the women respondents in this study said that they would be interested in participating in a peer-to-peer network. Women's interest in peer-to-peer education may be demonstrative of the concept of homophily, that women are more likely to feel welcome, more likely to participate and more willing to accept information from others with whom they feel similar. Although the theory of homophily is not directly discussed in any previous research on this topic, many papers describe the increased ability to talk with, feel comfortable with, and accept knowledge from someone who is your same gender (Leckie, 1996; Redmore, 2009; Trauger, et al., 2008).

Utilizing this research and previous research the conclusion is that through education and empowerment women could eliminate the social perception that forestry is a field meant specifically for males, allowing them to increase their involvement in forestry management as well as be more likely to attend forestry outreach education events. Previous studies have demonstrated that empowerment is the first step to breaking down the barriers that exist for women in forestry (Redmore, 2009) and that education can be the first step to empowerment 
(Allred \& Sagor, 2011; Page \& Czuba, 1999). Our suggestion is to take the management activities that women are already participating in (more so than others) such as tax preparation and recreational walking and incorporate woodland management into those topics. For instance on a walk in the woods look for invasive species or pests. It is also suggested that future research on the topic be done using qualitative methods asking similar questions so that results can be compared. 


\section{Literature Cited}

Allred, S. B., Goff, G. R., Wetzel, L. P., \& Luo, M. K. (2011). Evaluating peer impacts of a master forest owner volunteer program. J Extension, 49(5).

Allred, S. B., \& Sagor, E. (2011). Empowering woodland owners through peer learning. Journal of Forestry, 109(5), 303-304.

Barbercheck, M., Brasier, K., Kiernan, N. E., Sachs, C., Trauger, A., Findeis, J., . . Moist, L. (2009). Meeting the extension needs of women farmers: a perspective from Pennsylvania. Journal of Extension, 47(3), 82071-82000.

Biddle, B. J. (1986). Recent development in role theory. Annual review of sociology, 67-92.

Butler, B. J. (2008). Family forest owners of the United States, 2006. Gen. Tech. Rep. NRS-27. Newtown Square, PA: US Department of Agriculture, Forest Service, Northern Research Station, 73.

Butler, B. J., Miles, P. D., \& Hansen, M. H. (2013). National woodland owner survey table maker web application, version 1.0. Amherst, MA: USDA Forest Service, Northern Research Station.

Crawford, I. M. (1997). Marketing research and information systems: Food \& Agriculture Org.

Crim, S. D., Dubois, M., Bailey, C., \& Schelhas, J. (2003). Female forestland owners: characterization of assistance needs. Bugs, Budgets, Mergers, and Fire: Disturbance Economics, 129.

Culp, K., \& Pilat, M. (1998). Converting qualitative feedback into quantifiable categories. Journal of Extension, 36(5).

Eagly, A. H., Wood, W., \& Diekman, A. B. (2000). Social role theory of sex differences and similarities: A current appraisal. The developmental social psychology of gender, 123-174.

Effland, A. B., Rogers, D. M., \& Grim, V. (1993). Women as agricultural landowners: what do we know about them? Agricultural history, 235-261.

Hair, J., Anderson, R., Tatham, R., \& Black, W. (1998). Multivariate Data Analysis Prentice Hall. Upper Saddle River, NJ, 730.

Joshi, S., \& Arano, K. G. (2007). West Virginia forest landowners: a look at their characteristics and forest management decision. EMERGING ISSUES IN FOREST ECONOMICS, 13.

Joshi, S., \& Arano, K. G. (2009). Determinants of private forest management decisions: A study on West Virginia NIPF landowners. Forest Policy and Economics, 11(2), 132-139.

Leckie, G. J. (1996). Female farmers and the social construction of access to agricultural information. Library \& information science research, 18(4), 297-391.

Lidestav and Ekstrom, G., Magnus (2000). Introducing Gender in Studies on Management Behaviour Among Non-Industrial Private Forest Owners. Scandinavian Journal of Forest Research, 15(3), 378-386.

Matsunaga, M. (2010). How to Factor-Analyze Your Data Right: Do's, Don'ts, and How-To's. International Journal of Psychological Research, 3(1), 97-110.

McCuen, M., D.W. McGill, K.A. Arano, and S.Owen. (2013). West Virginia Woodland Welcome Wagon: Design, implementation, and evaluation in three priority areas. Journal of Extension.

McCuen, M., \& McGill, D. W. (2012). TO WHAT EXTENT ARE WOODLAND NEIGHBORS TALKING? AN ASSESSMENT OF INTERACTIONS BETWEEN ADJACENT WOODLAND OWNERS. Paper presented at the 18th Central Hardwood Forest Conference.

McGill, D. W., Grushecky, S. T., Moss, S., Pierskalla, C., \& Schuler, A. (2008). Landowner willingness to engage in long-term timber leases in West Virginia, USA. Small-Scale Forestry, 7(2), 105-116.

Mom, T. J., Bosch, F., \& Volberda, H. W. (2005). The influence of managerial and organizational determinants of horizontal knowledge exchange on competence building and competence leveraging: ERIM Report Series Research in Management.

Page, N., \& Czuba, C. E. (1999). Empowerment: What is it. Journal of Extension, 37(5), 1-5. 
Patil, V. H., Singh, S. N., Mishra, S., \& Donavan, D. T. (2008). Efficient theory development and factor retention criteria: Abandon the 'eigenvalue greater than one'criterion. Journal of Business Research, 61(2), 162-170.

PSUExtension. (n.d.). Building a Network of Women Forest Landowners. Penn State Extension.

Redmore, L. E. (2009). (Re) claiming forestry: a case study of women's empowerment.

Redmore, L. E., \& Tynon, J. F. (2011). Women Owning Woodlands: Understanding Women's Roles in Forest Ownership and Management. Journal of Forestry, 109(5), 255-259.

Reed, M. (2004). Equity in the Woods. Out of the Woods, 30(3).

Rogers, E. M. (2010). Diffusion of innovations: Simon and Schuster.

Sanders, H. C. (1966). The Cooperative Extension Service.

Santos, J. R. A., Mitchell, D., \& Pope, P. (1999). Are Open-Ended Questions Tying You in Knots. Journal of Extension, 37(4), n4.

SAS, I. (2011). 9.3 User's Guide. Cary, NC: SAS Institute Inc.

Stevens, J. (1992). Applied multivariate statistics for the social sciences.

Trauger, A., Sachs, C., Barbercheck, M., Kiernan, N. E., Brasier, K., \& Findeis, J. (2008). Agricultural education: Gender identity and knowledge exchange. Journal of Rural Studies, 24(4), 432-439.

Van Fleet, D. D., \& Atwater, L. (1997). Gender neutral names: Don't be so sure! Sex roles, 37(1-2), 111123.

Warren, S. T. (2003). One step further: Women's access to and control over farm and forest resources in the US South. Southern Rural Sociology, 19(2), 94-113.

Widmann, R. H., Cook, G. W., Barnett, C. J., Butler, B. J., Griffith, D. M., Hatfield, M. A., . . Perry, C. H. (2012). West Virginia's Forests 2008.

Wilent, S. (2013). Women and their Woods Program Educates and Motivates Woodland Owners. . The Forestry Source, 18(11).

WOCAN. (2012). Background Paper for the Scoping Dialogue on the Exclusion and Inclusion of Women in the Forestry Sector. The Forests Dialogue. 


\section{APPENDIX}

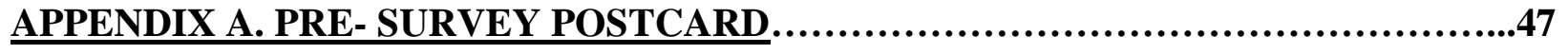

APPENDIX B. INITIAL COVER LETTER.........................................48

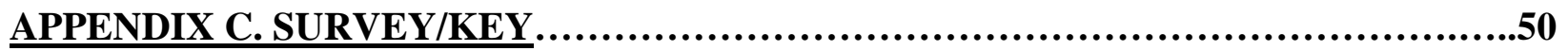

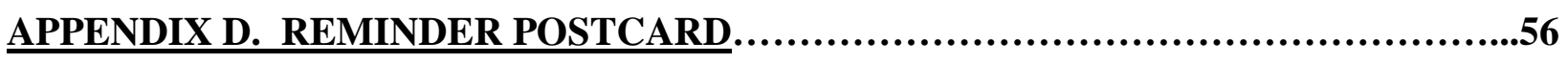

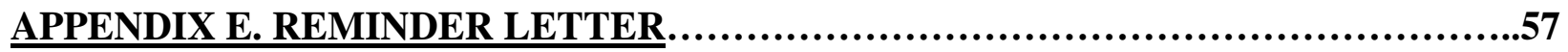




\section{APPENDIX A. Pre-survey postcard WWO, GWO}

Notice of Upcoming Survey

West Virginia Woodland Owners

Dear WV Woodland Owner:

A few days from now you will receive a questionnaire designed to collect

valuable information about woodland owners and help to guide state and local

agencies in designing appropriate outreach opportunities.

This is part of a research project that is being conducted by West Virginia

University. Acknowledgement of this study is on file with WVU's Institutiona Review Board.

Please look for this questionnaire in you mailbox. It is with your generous help that this research can be successful. Tha you in advance for your participation

Dave McGill Professor/Extension Specialist (304)293-5930; dmcgill@wru.edu

W. West VirginiaUniversity

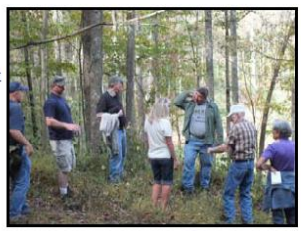

\section{Notice of Upcoming Survey}

West Virginia Woman Woodland Owners

Dear WV Woodland Owner:

A few days from now you will receive a questionnaire designed to collect information about West Virginia women woodland owners. Your insight can provide valuable information about woodland owners and help to guide state and local agencies in designing appropriate outreach opportunities.

This is part of a research project that is being conducted by West Virginia University. Acknowledgement of this study is on file with WVU's Institutional Review Board.

Please look for this questionnaire in your mailbox. It is with your generous help that this research can be successful. Thank you in advance for your participation.

Dave McGill

Professor/Extension Specialis (304) 293-5930; dmegill@wvu.edu

W-West VirginiaUniversity.

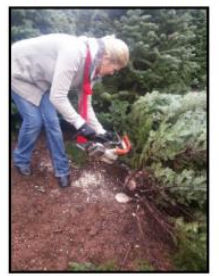




\section{APPENDIX B. Initial cover letter GWO}

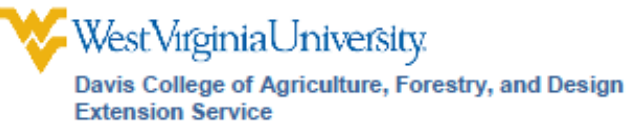

March 3, 2014

Dear West Virginia Woodland Owner:

We are writing to ask for your help in a research project to learn more information about West Virginia woodland owners. Please help us by taking a few minutes to fill out this survey.

We are sending this survey to private woodland owners in West Virginia to explore the goals and education opportunities woodland owners are seeking. Your insight can provide valuable information about woodland owners and ways in which they interact with their land and management decisions.

Please consider contributing your experience and knowledge to this research effort. Your participation in this survey is voluntary and you can quit at any time without penalty. You do not have to answer all of the questions, but any information you provide will contribute to the project's success. You must be over 18 years of age to participate. If you do not wish to participate, please let us know by returning the enclosed questionnaire, blank or with a note, in the prepaid envelope provided.

Information you provide is confidential; only summaries will be reported in which a single individual's answers cannot be identified. When you return your completed questionnaire, your name will be deleted from the mailing list and will not be connected to your answers in any way. Acknowledgment of this study is on file with West Virginia University's Institutional Review Board.

If you have any further questions, please feel free to contact us at the phone numbers below. Thank you in advance for your participation. It is with your generous help that our research can be successful.

Sincerely,

Dr. Dave McGill, Principal Investigator Professor/Extension Specialist Forest Resources Management (304) 293-5930

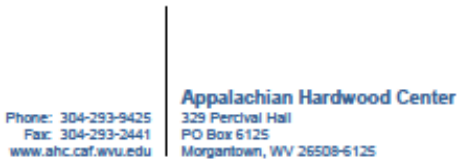

Tiffany Fegel

Graduate Research Assistant

WV FSP Outreach Education Coordinator

(304) 594-6478 


\title{
APPENDIX B. Initial cover letter WWO
}

\author{
West VirginiaUniversity \\ Davis College of Agriculture, Forestry, and Design \\ Extension Service
}

March 3, 2014

Dear West Virginia Woodland Owner:

We are writing to ask for your help in a research project to learn more information about West Virginia women woodland owners. Please help us by taking a few minutes to fill out this survey.

We are sending this survey to private woodland owners in West Virginia to explore the roles of women in woodland ownership. Your insight can provide valuable information about women woodland owners and ways in which they interact with their land and management decisions.

Please consider contributing your experience and knowledge to this research effort. Your participation in this survey is voluntary and you can quit at any time without penalty. You do not have to answer all of the questions, but any information you provide will contribute to the project's success. You must be over 18 years of age to participate. If you do not wish to participate, please let us know by returning the enclosed questionnaire, blank or with a note, in the prepaid envelope provided.

Information you provide is confidential; only summaries will be reported in which a single individual's answers cannot be identified. When you return your completed questionnaire, your name will be deleted from the mailing list and will not be connected to your answers in any way.

Acknowledgment of this study is on file with West Virginia University's Institutional Review Board.

If you have any further questions, please feel free to contact us at the phone numbers below. Thank you in advance for your participation. It is with your generous help that our research can be successful.

Sincerely,

Dr. Dave McGill, Principal Investigator Professor/Extension Specialist Forest Resources Management (304) 293-5930
Tiffany Fegel

Graduate Research Assistant

WV FSP Outreach Education Coordinator

(304) 594-6478 


\section{West Virginia Woodland Owner Needs Assessment}

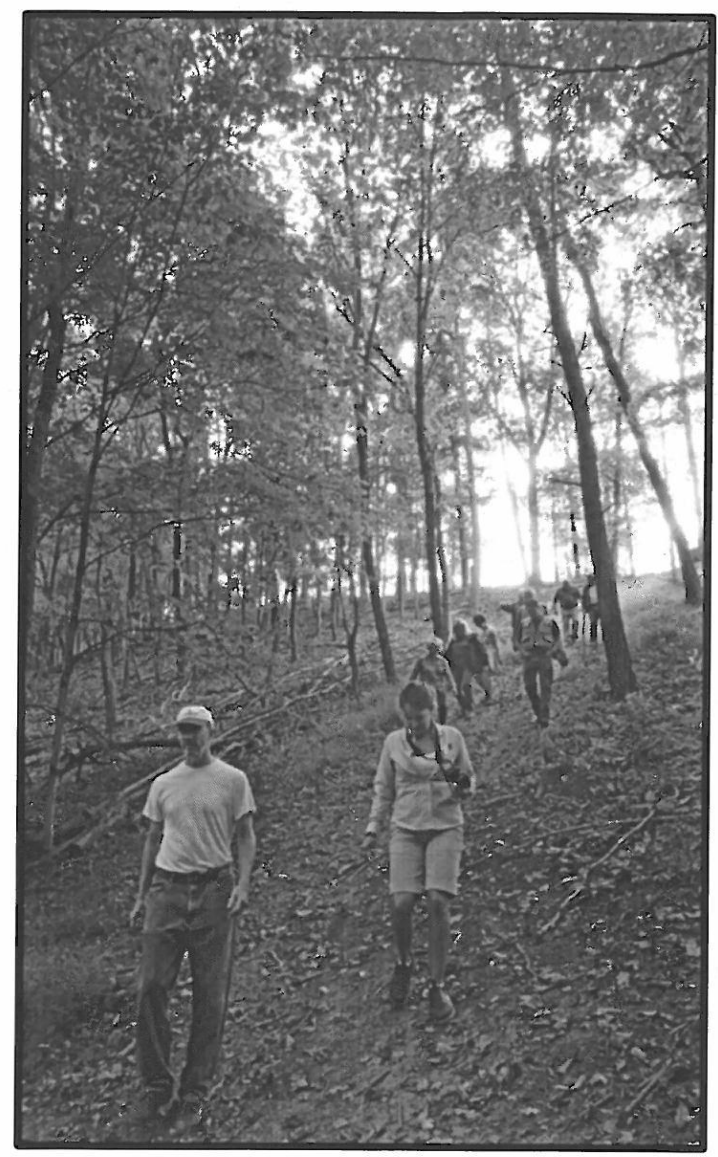

March 2014

Research conducted in accordance with:

Extension Service

WestVirginiaUniversity:

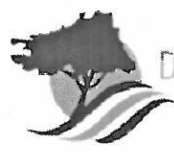

FORESTRY
If you have any questions please contact:

Tiffany Fegel

West Virginia University

Division of Forestry \& Natural Resources P.O. Box 6125, Morgantown, WV 26506 Email:T.fegel@aol.com Phone: $971-409-4030$ 
About This Research

The purpose of this research is to assess the potential for extension outreach education opportunities for woodland owners in West Virginia. Non-industrial private woodlands make up the majority of the landscape in the eastern United States making woodland owners an integral part in the management of West Virginia's forests.

The goals of this project are to understand:

- the educational preferences of woodland owners;

current management decisions, responsibilities, and actions occurring on properties;

Woodland is defined in this research as any parcel of land that is covered by trees.

Your participation is voluntary and you have the right to refrain from answering any questions. If you choose to participate, your answers will be kept confidential.

Thank you for your assistance with this important research!

Please return the completed questionnaire in the postage-paid envelope provided.

\section{START HERE:}

results $\square$ I am interested in receiving a summary of the results of this survey. if checked $=1$

Please read carefully the following items and check all that apply:

Woodland1 $\square \quad$ I do own woodland property (continue with questionnaire). Jodland2 $\square \quad$ Ido not own woodland property (please return blank questionnaire). if not

Wivodland $3 \square \quad$ I prefer not to participate in this survey (please return blank questionnaire).

if checked = 1 chered $=\varnothing$

\section{Woodland property ownership}

Q1 1) With respect to the woodland property you own in West Virginia that you live on or visit most frequently:

a. What is the size of this property? Q $1 \mathrm{~A}$ Acres

b. Approximately how much of this property is woodland? Q1B Acres

c. In what county is this property? Q1C

d. In what year was this property acquired? Q1D

e. Do you reside on this property? 1 Yes 2 No

Q1EA f. If No, do you have future plans to live on this property?
2 Yes
2 No

Q2 2) What are the 3 top reasons for owning your property? (List here)
a.
Q2n
b. Q. B
c. Q2 $C$

Q3 3) Which category below best describes your ownership? (Check one)
1 Individual
4 Joint (e.g. husband and wife)
2. Family partnership
5 Corporation or business partnership
3 Trust or estate
Other (please specify)

Q4 4) How many people are a part of your woodland ownership? 
Q55) Are you planning to sell or transfer your property in the next 10 years? (Check one)
1. Yes
2 No (if no, skip to question 6)

If the answer is yes,

Q5A 5b) Who will the property be sold or transferred to?
1 Family
2 Neighbor
3 Other:

Q6 6) How did you acquire this woodland in West Virginia? (Check all that apply)
1 Purchased
3 Inherited
2 Received as gift
4 Other (please specify)

\section{Woodland activities}

Q7 7) Have you ever contacted a professional forester about your woodland property? (Check one)

1 Yes 2 No

Q 8 8) Do you currently have a written Forest Stewardship Plan for your woodland? (Check one)
1. Yes 2 No
3 I don't know
4. I have contacted a forester, but do not have the plan yet.

Q9 9) Have you ever sold timber from this property? (Check one)
1 Yes
2 No

Q 10 10) Have you ever been contacted about selling the timber on this property? (Check one)

1 Yes 2 No

Q 11 11) In the next ten years, how likely is it that you will sell timber? (Check one)

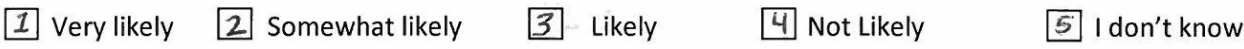

\section{Management}

Q 12 12) Name a few people that you talk to for advice regarding management decisions on your woodland property. (you can use relationships or roles; for example: sister, forester, lawyer, agency, organization)
a. Q12A
b. Q12B
c. Q12C

Q 13 13) Who makes the majority of the management decisions for your woodland? (Check one)
I I do
2 Joint decisions by owners
3 Other:

Q 14 14) Fill in how many times per month you do the following activities:

Communicate with neighbors
Walk the property
Photograph nature on the property
Clean-up the property
Visit the property (if resident write "NA") 14 E times times times per month


Q 15 15) Please indicate whether you or others undertake the following tasks. If both you and others do these, describe who helps you. If others, please describe (e.g. significant other, neighbor, forester). (Check all that apply)

Activity
Q15A Sell timber

Q16 16) Describe your primary role in the management of your woodland.

Q17 17) What do you appreciate or enjoy most about your woodland?

Q18 18) What are the main challenges you face with managing your woodland? 


\section{Interest in Woodland Topics}

Q19 19) Please circle your interest level in the following topics for seminars and workshops: (Circle one number for EACH)

\begin{tabular}{|c|c|c|c|c|c|}
\hline & I would be likely to participate in a workshop regarding... & Not Likely & $\begin{array}{c}\text { Somewhat } \\
\text { Likely }\end{array}$ & Likely & Very Likely \\
\hline QPA & ... Managing for wildlife & 1 & 2 & 3 & 4 \\
\hline$B$ & ....Timber harvest & 1 & 2 & 3 & 4 \\
\hline C & ... Non-timber forest products & 1 & 2 & 3 & 4 \\
\hline D & ...Stewardship & 1 & 2 & 3 & 4 \\
\hline$E$ & ...Land transfer & 1 & 2 & 3 & 4 \\
\hline$F$ & ...State incentive programs & 1 & 2 & 3 & 4 \\
\hline$G$ & ...Forestry terms (Diameter breast height, merchantable height) & 1 & 2 & 3 & 4 \\
\hline$H$ & ... Using equipment (chainsaw, power tools, tractor) & 1 & 2 & 3 & 4 \\
\hline$I$ & ... Marketing timber & 1 & 2 & 3 & 4 \\
\hline 丁 & ... Creating more productive timber lands & 1. & 2 & 3 & 4 \\
\hline$k$ & ... Creating deer habitat & 1 & 2 & 3 & 4 \\
\hline L & ... Identifying wildlife species & 1 & 2 & 3 & 4 \\
\hline m & ... Bird watching/identifying & 1 & 2 & 3 & 4 \\
\hline$N$ & ... Trapping and hunting wildlife & 1 & 2. & 3 & 4 \\
\hline 0 & ... How to measure timber value & 1 & 2 & 3 & 4 \\
\hline P & ... Medicinal herbs (ginseng, goldenseal) & 1 & 2 & 3 & 4 \\
\hline Q & ... Forest grown mushrooms (shiitake, chanterelle) & 1 & 2 & 3 & 4 \\
\hline$R$ & ... Other: & 1 & 2 & 3 & 4 \\
\hline
\end{tabular}

Q2020) Please circle your interest level in the following formats of seminars and workshops: (Circle one number for EACH) Not Somewhat Interested Very

I would be interested in participating in a... Interested Interested Interested Interested

\begin{tabular}{|c|c|c|c|c|}
\hline OA ... Weekend workshop & 1 & 2 & 3 & 4 \\
\hline B ... Meeting hosted in the woods of a woodland owner & 1 & 2 & 3 & 4 \\
\hline ... Indoor meeting with natural resource professionals & 1 & 2 & 3 & 4 \\
\hline D ... Meeting using PowerPoint presentations & 1 & 2 & 3 & 4 \\
\hline$E$... Online webinar & 1 & 2 & 3 & 4 \\
\hline$F$... Discussion with other forest owners & 1 & 2 & 3 & 4 \\
\hline G ... Event for families (including children's activities) & 1 & 2 & 3 & 4 \\
\hline It ... Event with instructors who are my same gender & 1 & 2 & 3 & 4 \\
\hline I ... Discussion with natural resource professionals & 1 & 2 & 3 & 4 \\
\hline J ... Demonstration in the forest & 1 & 2 & 3 & 4 \\
\hline K ... Weekday evening workshop & 1 & 2 & 3 & 4 \\
\hline$L$... Network of other forest owners & 1 & 2 & 3 & 4 \\
\hline$M \quad$... Question and answer session & 1 & 2 & 3 & 4 \\
\hline N ... Other: & 1 & 2 & 3 & 4 \\
\hline
\end{tabular}


Q21 21) I would feel most comfortable at a workshop with: (Check one)

1 Mostly women

2 Mostly men

3 Mixture of both

Q22 22) Have you ever felt that your experience at a seminar has been affected by your gender? Please describe:

23) Describe your ideal seminar/workshop:

Demographics

Please answer the following questions about yourself:

Q2323 23) What is your gender? 1 Female 2 Male

Q24 24) What is your age?

$\begin{array}{lll}1318-30 y r s & 340-50 & 560-70 \\ 230-40 & 450-60 & 670+\end{array}$

Q25 25) What is your current occupation?

Q26 26) Ireside in: Q26A county Q26B state

Q27 27) What is the highest level of education you have completed? (Check one)
1. Some High School
(6) Associates degree
2 High School Graduate
7 Bachelor's degree
3 GED
(:) Master's degree
4. Trade or Technical School
9 Ph.D
5 Some college

028 28) What is your average yearly income? (Check one)

\begin{tabular}{ll}
\hline Less than $\$ 15,000$ & $5 \$ 60,001-\$ 75,000$ \\
\hline $2 \$ 15,001-\$ 30,000$ & $6 \$ 75,001-\$ 90,000$ \\
$3 \$ 30,001-\$ 45,000$ & $7 \$ 90,001+$ \\
$4 \$ 45,001-\$ 60,000$ &
\end{tabular}

Thank you for completing this survey, your input is important!

Please return the completed questionnaire in the postage-paid envelope provided. 


\title{
APPENDIX D. Reminder postcard GWO
}

\author{
Reminder About Important Survey \\ West Virginia Woodland Owners \\ Dear WV Woodland Owner:
}

A couple weeks ago we mailed a survey designed to collect information about West Virginia woodland owners. If you have already completed and returned the survey, please accept our sincere thanks. If not, please take a few minutes to do so today.

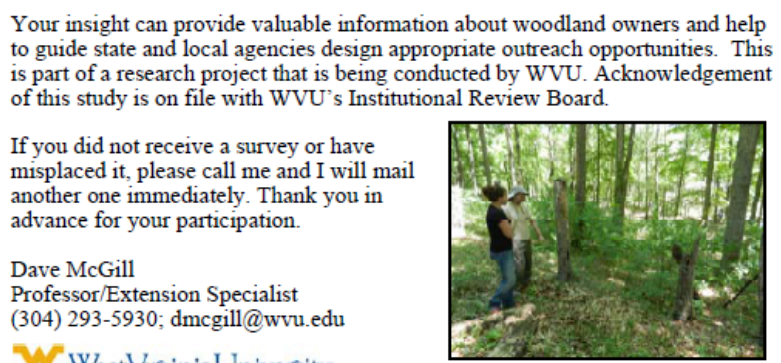

West WirginiaUniversity.

\section{APPENDIX D. Reminder postcard WWO}

\section{Reminder About Important Survey}

\section{West Virginia Women Woodland Owners}

Dear WV Woodland Owner:

A couple weeks ago we mailed a survey designed to collect information about West Virginia women woodland owners. If you have already completed and returned the survey, please accept our sincere thanks. If not, please take a few minutes to do so today.

Your insight can provide valuable information about woodland owners and help to guide state and local agencies design appropriate outreach opportunities. This is part of a research project that is being conducted by WVU. Acknowledgement of this study is on file with WVU's Institutional Review Board.

If you did not receive a survey or have misplaced it, please call me and I will mail another one immediately. Thank you in advance for your participation.

Dave McGill

Professor/Extension Specialist (304) 293-5930; dmcgill@wvu.edu

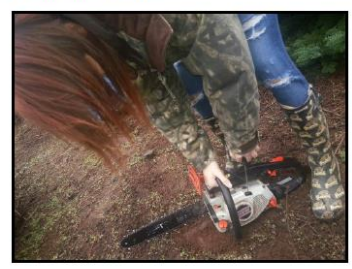

W-WestVurginiaUniversity. 


\title{
APPENDIX E. Reminder cover letter GWO
}

\author{
WestVirginiaUniversity \\ Davis College of Agriculture, Forestry, and Design \\ Extension Service
}

March 24, 2014

Dear West Virginia Woodland Owner:

About a month ago we mailed you a questionnaire that is part of a West Virginia University research project to learn more information about West Virginia woodland owners. According to our records, you have not yet returned the survey.

We are writing again because your participation in this survey is important to get accurate results. It is by hearing from the majority of our sample population that we get a representative view of the roles of West Virginia woodland owners. Please consider contributing your experience and knowledge to this research effort.

Again, your participation in this survey is voluntary and you can quit any time without any penalty. You do not have to answer all of the questions, but any information you provide will contribute to the project's success. You must be over 18 years of age to participate. If you do not wish to participate, please let us know by returning the enclosed questionnaire, blank or with a note, in the prepaid envelope provided.

Information you provide is confidential; only summaries will be reported in which no individual's answers can be identified. When you return your completed questionnaire, your name will be deleted from the mailing list and will never be connected to your answers in any way.

Acknowledgment of this study is on file with West Virginia University's Institutional Review Board.

If you have any further questions, please feel free to contact us at the phone numbers below. It is with your generous help that our research can be successful.

Sincerely,

Dr. Dave McGill, Principal Investigator Professor/Extension Specialist

Forest Resources Management

(304) 293-5930
Tiffany Fegel

Graduate Research Assistant

WV FSP Outreach Education Coordinator

(304) 598-6478

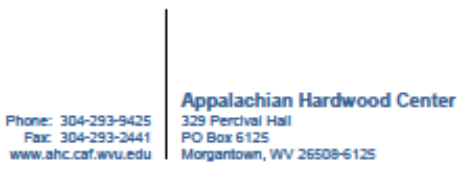




\title{
APPENDIX E. Reminder cover letter WWO
}

\author{
WestVirginiaUniversity \\ Davis College of Agriculture, Forestry, and Design \\ Extension Service
}

March 24, 2014

Dear West Virginia Woodland Owner:

About a month ago we mailed you a questionnaire that is part of a West Virginia University research project to learn more information about West Virginia women woodland owners. According to our records, you have not yet returned the survey.

We are writing again because your participation in this survey is important to get accurate results. It is by hearing from the majority of our sample population that we get a representative view of the roles of West Virginia women woodland owners. Please consider contributing your experience and knowledge to this research effort.

Again, your participation in this survey is voluntary and you can quit any time without any penalty You do not have to answer all of the questions, but any information you provide will contribute to the project's success. You must be over 18 years of age to participate. If you do not wish to participate, please let us know by returning the enclosed questionnaire, blank or with a note, in the prepaid envelope provided.

Information you provide is confidential; only summaries will be reported in which no individual's answers can be identified. When you return your completed questionnaire, your name will be deleted from the mailing list and will never be connected to your answers in any way. Acknowledgment of this study is on file with West Virginia University's Institutional Review Board.

If you have any further questions, please feel free to contact us at the phone numbers below. It is with your generous help that our research can be successful.

Sincerely,

Dr. Dave McGill, Principal Investigator Professor/Extension Specialist

Forest Resources Management (304) 293-5930
Tiffany Fegel

Graduate Research Assistant

WV FSP Outreach Education Coordinator

(304) 598-6478 